\title{
Deposit Insurance, Bank Incentives, and the Design of Regulatory Policy
}

\author{
Paul H. Kupiec and James M. O'Brien ${ }^{1}$ \\ Division of Research and Statistics \\ Board of Governors of the Federal Reserve System \\ Washington, D.C. 20551
}

December 1997

\begin{abstract}
This study analyzes the efficacy and efficiency of alternative bank regulatory policies within a theoretical framework that is general enough to encompass many issues relevant for policy design. We revisit the existing literature and consider the consequences of generalizing banks' investment and financing opportunities as they relate to the design of bank capital regulation and deposit insurance pricing. When equity issuance is costless, a common modeling assumption, narrow banking costlessly resolves the moral hazard inefficiencies and insurance pricing problems addressed in this literature. When equity issuance is costly, minimum capital requirements can still be effective, but optimal policy design is complicated by its dependence on equity issuance costs, heterogeneous bank investment opportunity sets, and the substantial information requirements that these dependencies create. Incentivecompatible policy mechanisms, while potentially useful in certain circumstances, appear limited in their ability to resolve the information problems.
\end{abstract}

\footnotetext{
${ }^{1}$ Correspondence: James O'Brien, Division of Research and Statistics, Board of Governors of the Federal Reserve System, Washington, D.C. 20551; Tel: (202) 452-2384, Fax: (202) 452 3819, E-Mail: jmobrien@frb.gov. The conclusions herein are those of the authors and do not represent the views of the Federal Reserve Board or any of the Federal Reserve Banks. We are grateful to Greg Duffee and Mark Fisher for useful discussions and to Pat White, Mark Flannery, and Erik Sirri for helpful comments.
} 


\section{Introduction}

A large literature studies the incentives created by fixed-rate deposit insurance and regulatory policies intended to control the moral hazard problems that are engendered by the deposit guarantee. Because individual results are established in a heterogeneous set of stylized models, it is difficult to assess their generality or to assimilate them into a working model of a bank. This study revisits this literature and attempts to clarify and extend our understanding of alternative policies that attempt to regulate the behavior of institutions that are financed with insured deposits. Our theoretical framework relaxes previous stylizations and is able to encompass many issues relevant for policy design.

The analysis assumes that banks maximize net shareholder value in a two-period setting by investing in positive net present value (NPV) loans, risk-free bonds, and risky 0 NPV market-traded securities. Our procedures for modeling a bank's loan investment opportunity set are novel. While we impose absence-of-arbitrage conditions in accounting for risk in loan valuations, we do not impose any ad hoc functional relationship between loan risk and NPV. Because deposit-taking is assumed to be profitable and banks have positive NPV loan investment opportunities, banks also have positive going-concern value. Banks have access to capital markets and can finance their investments with equity or insured deposits and may re-capitalize to avoid default. Outside equity issuance may be costly, and these costs may differ depending on whether or not a bank is in a financial distress situation.

Our results highlight the importance of modeling assumptions that characterize the attributes of individual bank's investment opportunity sets and financing alternatives for the design of capital regulatory policy and deposit insurance pricing. Assuming banks can invest in risky market-traded securities, we show that fixed-rate deposit insurance can create a moral hazard incentive that encourages banks to take excessive risk and to under-invest in positive NPV loans. If, however, banks can hold a risk-free asset (e.g., Treasury bills), there exists a minimum capital requirement policy that 
will attenuate moral hazard without inhibiting the issuance of insured deposits. If equity issuance is costless, a type of narrow banking requirement removes moral hazard incentives in an efficient manner. More realistically, when equity issuance is costly, an efficient regulatory capital policy will entail bank-specific capital requirements. The implementation of such a policy is, however, problematic as supervisors must acquire information equal to that of the bank manager. Our analysis further suggests that incentive-compatible mechanisms are likely to be limited in their ability to resolve regulatory information problems and as a consequence need not dominate other regulatory approaches. The aforementioned results contrast with those appearing in the literature. We argue that specialized modeling assumptions have been important for many of the results previously established. To put this more concretely, we review some of the important issues that have been debated in this branch of the banking literature.

Regulatory polices that supplement fixed-rate deposit insurance are broadly aimed at limiting unintended wealth redistributions and correcting the inefficient resource allocations that result from risk-insensitive premium rates. According to a number of studies, the inefficiency of fixed-rate deposit insurance comes from over-investment in risky loans, to the point where banks find it optimal to finance negative NPV investments (Gennotte and Pyle (1991), Chan, Greenbaum, and Thakor (1992), John, John, and Senbet (1991), Craine (1995)). We show that this result depends on the restrictive assumption typically imposed that a bank's investment opportunity set has an NPV that is a concave function of the level of risk exposure. Alternatively, if banks can invest in sufficiently risky 0 NPV securities, the inefficiency created by fixed-rate deposit insurance owes to under-investment in positive NPV investment opportunities.

Minimum capital requirements constitute a principal policy tool for countering the moral hazard incentives of fixed-rate deposit insurance and protecting the deposit insurer. While many view minimum regulatory capital requirements as an effective 
policy tool (e.g., Keeley and Furlong (1991), Gjerde and Semmen (1995)), others have argued that an increase in minimum capital requirements can create incentives for additional risk-taking (Koehn and Santomero (1980), Kim and Santomero (1988b), Gennotte and Pyle (1991), Rochet (1992)). We show, however, that if a bank can invest in an identifiable risk-free security, there always exists a moral hazard-attenuating minimum capital requirement. This capital requirement will not affect the amount of insured deposits and it is effective even when bank investment opportunities include private-information loans.

A potential alternative to capital regulation is to price the insurance so that it reflects the risk in the bank's asset portfolio (e.g., Merton (1977), Ronn and Verma (1986)). However, the argument is made that risk-sensitive insurance premiums are impossible without some form of (possibly government-supported) deposit rents (Buser, Chen, and Kane (1981), Chan, Greenbaum, and Thakor (1991), Craine (1995)). Besides specializing the risk and return characteristics of banks' loan investment opportunity sets, the models underlying this argument assume unrestricted access to equity capital at the risk-free rate on a risk-adjusted basis (no equity issuance costs) and preclude opportunities for banks to invest in risk-free (and risky) 0 NPV market-traded securities. With zero equity issuance costs, if the models are amended to allow investment in a risk-free security, a policy requiring full collateralization of insured deposits with the risk-free asset and a zero insurance premium is a fair-pricing policy that also produces efficient lending decisions. This solution is a form of narrow banking (e.g., Litan (1987) and Merton and Bodie (1993)) and is similar to Craine's (1995) efficient fair-pricing solution but does not necessitate any changes in bank charter policy.

Recognizing equity issuance costs greatly complicates the design of regulatory policy. When equity issuance is costly, regulatory schemes that involve capital requirements, including narrow banking, can impose significant dead-weight costs on bank shareholders and discourage positive NPV investments. An efficient regulatory 
policy - one that achieves fair risk-based insurance premiums and minimizes regulatory costs - is bank-specific and will vary with the characteristics of individual banks' investment opportunity sets and financing costs. Although equity issuance costs and heterogeneity of investment opportunity sets across banks are fundamental to the design of regulatory policy, their importance has not been adequately recognized in the literature because of oversimplifications in bank modeling.

Incentive-compatible regulatory mechanisms have been suggested as a way of solving information problems regulators face in designing an optimal policy. ${ }^{2}$ While incentive-compatible schemes work in the context of the stylized models in which they are developed, their potential role appears to be limited under more general and realistic investment opportunity and financing assumptions. ${ }^{3}$ This owes to both the heterogeneity of investment opportunity sets and regulators highly limited knowledge of bank investment opportunity sets, as well as to heterogeneity in other bank parameters such as equity issuance costs.

\section{Bank Shareholder Value and Economic Value}

\subsection{Model Assumptions}

The bank makes investment and financing decisions in period 1 so as to maximize the net present value of shareholders' claims on future bank cash flows. On the asset side, the bank may choose to invest in 1-period risky non-traded loans, risk-free discount bonds, and risky market-traded securities.

The end-of-period values of individual loans or risky securities have lognormal distributions. Accordingly, the end-of-period value of a generic investment in a loan or risky security, $j_{i 1}$, is given by,

\footnotetext{
${ }^{2}$ For example, see Chan, Greenbaum, and Thakor (1992), Giammarino, Lewis, and Sappington (1993), Kim and Santomero (1988a), John, John, and Senbet (1991), Campbell, Chan, and Marino (1992), and John, Saunders, and Senbet (1995).

${ }^{3}$ Campbell, Chan, and Marino (1992) also suggest limitations on incentive-compatible approaches.
} 


$$
j_{i 1}=V_{i 0} e^{\mu_{i}+s_{i}^{\top} z}
$$

where $V_{i 0}$ is the initial investment; $\mu_{i}$ is the expected rate of return on the investment; $s_{i}$ is a vector of volatilities (superscript $T$ denotes transpose); and $z$ is a vector of independent standard normal shocks.

The risk-adjusted present value of the investment, $j_{i 0}$, is given by,

$$
j_{i 0}=V_{i 0} e^{\mu_{i}+\frac{1}{2} \sigma_{i}^{2}-\lambda^{\top} s_{i}-r}
$$

where, $\lambda$ is a vector of the market prices of investment $i$ 's risk factors (non-systematic risks have a zero price), $\sigma_{i}^{2}=s_{i}^{\top} s_{i}$ is the return variance, and $r$ is the 1-period risk-free rate. ${ }^{4}$ Investments in market-traded securities satisfy the market equilibrium return condition, $\mu_{M}+\frac{1}{2} \sigma_{M}^{2}-\lambda^{\top} s_{M}-r=0$, and as a consequence are 0 NPV investments. Individual loans are discrete investment opportunities that are not traded. Because banks may have exclusive access to some lending opportunities, loans can be positive NPV investments, i.e., $j_{L_{i} 0}-I_{i}>0$, where $I_{i}$ is the bank's investment in loan i. For a positive NPV loan, $\mu_{L_{i}}+\frac{1}{2} \sigma_{L_{i}}^{2}-\lambda^{\top} s_{L_{i}}-r>0$. The total bank investment in risk-free bonds is denoted by $T$.

As individual loans are discrete investments, a bank's loan investment opportunity set is defined to be the set of all possible combinations of the discrete lending opportunities it faces. Each loan has an associated investment requirement, NPV, and set of risk characteristics. While financial market equilibrium (absence of arbitrage) requires that the expected returns on traded assets be linearly related to their priced risk components, this condition places no restrictions on the relationship between the NPV and risk of non-traded assets. Assets with positive NPV are expected to return to bank shareholders more than their market equilibrium required rates of return. For such assets, there are no equilibrium conditions that impose a relationship

\footnotetext{
${ }^{4}$ For simplicity, $r$ is non-stochastic. See Appendix for a formal derivation of (2).
} 
among NPV, investment size, or risk. Thus, a bank's loan investment opportunity set could be characterized by a wide variety of investment size, loan portfolio NPV, and risk combinations. ${ }^{5}$

The bank finances its investments with a combination of internal equity capital, external equity, and deposits. End-of-period deposit values are government insured against default. Internal equity, $W$, represents the contribution of the initial shareholders. Outside equity financing, E, generates issuance costs of $d_{0} \geq 0$ per dollar of equity issued. Issuance costs include normal transactions fees as well as any implicit asymmetric information costs that may in part take the form of payments to auditors and underwriters for certifying the value and risk of the issue.

While deposit accounts provide liquidity services, the model abstracts from withinperiod deposits and withdrawals and treats these accounts as equivalent to 1-period discount bonds with an aggregate par value of $B$. As deposits are insured, their required return is equal to the 1-period risk-free rate, $r$, less a charge for liquidity services. The service charge net of servicing costs earns the bank a profit of $\pi$ per dollar of deposits. Both the transactions account fees and the bank's deposit insurance premium payments, denoted by $\phi B e^{-r}$, are paid at the beginning of the period. The bank has a maximum deposit base of $\bar{B}$ (par value), perhaps for geographical reasons. ${ }^{6}$

\footnotetext{
${ }^{5}$ Our unrestricted characterization of the loan investment opportunity set differs from the approaches used in previous studies that have addressed the positive NPV nature of loan investment opportunities (e.g., Gennotte and Pyle (1991), Rochet (1992), Chan, Greenbaum and Thakor (1992), and Craine (1995)). These studies assume a well-defined opportunity locus between loan portfolio NPV and risk. While theoretically convenient for generating closed-form optimality conditions, such an assumption appears to be without theoretical basis or formal empirical support. Even if a bank's choices can be limited to a subset of loan portfolios, a so-called "efficient" set, this subset cannot be determined independent of the bank's preferences for risk, as well as NPV. For example, a bank attempting to minimize default risk may rank loans by solving something analogous to an efficient frontier problem for loan portfolios; that is, for any level of loan portfolio NPV, it would identify the set of loans with minimum risk. However, a bank attempting to exploit its deposit insurance guarantee would not necessarily choose a member of this efficient frontier. For instance, it may shun diversification (see Green (1984), p. 123).

${ }^{6}$ The constant profit rate on deposits is a simplification to avoid modeling the liquidity services provided by deposit accounts. With a constant profit rate, a maximum deposit issuance limit is necessary to avoid infinite deposit issuance as an optimal policy. Alternatively, we could assume a convex cost of supplying transactions accounts.
} 
In the model, short-selling of securities -including derivatives transactions that create implicit short positions - is prohibited. The potential liabilities created by short positions are not insured. As a consequence, short positions expose a bank's counter-parties to default (credit) risk that must be priced. Pricing requires estimates of risk exposures and short securities positions may introduce significant complications in the valuation of the deposit insurance guarantee. ${ }^{7}$

At the end of the first period, the bank's cash-flows from its loans, risky securities, and risk-free bonds are used to payoff depositors. Shareholders receive any excess cash flows and retain rights to the bank's franchise value, $J$, whose value is assumed to be fixed. ${ }^{8}$ If cash flow is insufficient to meet depositors' claims $(B)$, the bank may issue equity against its franchise value. However, equity issued against $J$ to finance end-ofperiod cash flow shortfalls generate "distress issuance costs" of $d_{1} \geq 0$ per dollar of equity issuance. As with equity sales in non-distress periods, distress issuance costs would include both transactions fees and costs for certifying the value of the issue. The deposit insurer closes the bank if it cannot satisfy its existing deposit liabilities. ${ }^{9}$

\subsection{Bank Shareholder Value}

Let $L$ represent the set of individual loans in the bank's optimal loan portfolio. Under these assumptions, the net present value of initial shareholder's claims is given by, ${ }^{10}$

$$
\begin{aligned}
S & =j_{L 0}-I+e^{-r} J+\pi B e^{-r}+P_{I}-\phi B e^{-r} \\
& -\frac{d_{1}}{1-d_{1}}\left(P_{D}-P_{I}\right)-\frac{d_{0}}{1-d_{0}} E
\end{aligned}
$$

\footnotetext{
${ }^{7}$ In reality, pricing credit risk is more complicated. If a model includes equity issuance costs that arise in part from asymmetric information, then pricing contracts under the assumption that defaulting states are known a priori by counter-parties will lead to valuation inconsistencies. For logical consistency, a model that assumes outside equity issuance is costly owing to asymmetric information must also reflect such costs in the pricing of credit risk exposures as the asymmetric information problems of the bank's counter-parties are analogous to those of its outside investors.

${ }^{8}$ Franchise value may arise from continuing access to positive NPV loan opportunities, the ability to offer transactions accounts at a profit, and the net value of deposit insurance in future periods.

${ }^{9}$ The insurer's costs when the bank is closed are defined below.

${ }^{10} \mathrm{~A}$ derivation is given in the appendix.
} 
where $E=\max \left\{\left(I+T+M+\phi B e^{-r}-(1+\pi) B e^{-r}-W\right), 0\right\}$,

and

$$
I=\sum_{\forall j \in L} I_{j}, \quad j_{L 0}=\sum_{\forall j \in L} j_{L_{j} 0}
$$

The components of shareholder value follow: $j_{L 0}-I$ is the net present value of the bank's loan portfolio; $e^{-r} J$ is the present value of the bank's end-of-period franchise value; $B e^{-r} \pi$ are the profits from deposit-generated fee income; $P_{I}-\phi B e^{-r}$ is the net value of deposit insurance to bank shareholders. $P_{I}$ has a value equivalent to that of a simple European put option written on the bank's total asset portfolio with a strike price of $j_{d}=B-T e^{r}-\left(1-d_{1}\right) J$. This strike price is the cash flow value below which the bank's shareholders find it optimal to default on the bank's deposit liabilities. For $j_{d} \leq 0, P_{I} \equiv 0$.

The second line in expression (3) captures the costs associated with outside equity issuance. $E$ covers any financing gap that remains after deposits, inside equity, and deposit profits net of the insurance premium, $(\pi-\phi) B e^{-r}$, are exhausted by the bank's investments. Each dollar of external finance generates $d_{0}$ in issuance costs, requiring that $\frac{1}{1-d_{0}}$ dollars of outside equity be raised. $\frac{d_{1}}{1-d_{1}}\left(P_{D}-P_{I}\right)$ is the initial value of the contingent liability generated by end-of-period distress costs. The distress costs are proportional to the difference between two simple put options, $P_{D}$ and $P_{I}$, where both options are defined on the underlying value of the bank's asset portfolio. $P_{D}$ is the value of a put option with a strike price of $j_{d s}=B-T e^{r}$, the threshold value below which the bank must raise outside equity to avoid default. The strike prices of these options define the range of cash-flow realizations, $\left(j_{d}, j_{d s}\right)$, within which shareholders bear financial distress costs. ${ }^{11}$ Distress costs reduce shareholder value since $P_{D} \geq P_{I}$.

\footnotetext{
${ }^{11} \frac{d_{1}}{1-d_{1}} P_{D}$ is a hypothetical value of the distress costs the bank would face if it could not default on its deposit obligations. Because bank shareholders will not have to bear distress costs for portfolio value realizations less than $j_{d}$, the default threshold, the term, $\frac{d_{1}}{1-d_{1}} P_{I}$ credits shareholders with the default portion of the distress costs.
} 


\subsection{Shareholder Value Maximization}

The shareholder value function, $S$, must be optimized using integer programming methods. This is necessitated by the assumption that loans are discrete non-tradeable investments with individualized risk and return characteristics.

Let $j_{L_{k} 0}$ represent the risk-adjusted present value of loan portfolio $k$ that can be formed from the bank's loan investment opportunity set. The loan portfolio has a required investment of $I_{k}$ and an NPV equal to $j_{L_{k} 0}-I_{k}$. The bank shareholder maximization problem can be written as,

$$
\max S=e^{-r} J+\max _{\forall k}\left\{\left(j_{L_{k} 0}-I_{k}\right)+\max \left\{\left.\mathrm{K}\left(L_{j}\right)\right|_{L_{j}=L_{k}}\right\}\right\}
$$

where

$$
\mathrm{K}\left(L_{j}\right)=P_{I}+(\pi-\phi) B e^{-r}-\frac{d_{0}}{1-d_{0}} E-\frac{d_{1}}{1-d_{1}}\left(P_{D}-P_{I}\right)
$$

and $\left.\mathrm{K}\left(L_{j}\right)\right|_{L_{j}=L_{k}}$ indicates that the function $\mathrm{K}$ is to be evaluated conditional on the loan portfolio $L_{k}$. The conditional value of $\mathrm{K}$ is maximized over $T, M, B, W$, and the risk characteristics of the market-traded securities portfolio with $E$ satisfying the financing constraint in equation (3), $B \in(0, \bar{B})$ and $I, T, M, W, E \geq 0$. Thus, for each possible loan portfolio (including the 0 investment loan portfolio), the bank maximizes the portfolio's associated $\mathrm{K}$ value by making the appropriate investment choices for risk-free and risky securities, outside equity issuance, and inside capital (or dividend pay-out policy). The bank then chooses the loan portfolio for which the sum of loan portfolio NPV and associated maximum $\mathrm{K}$ value is the greatest.

\subsection{Bank Economic Value-Added}

In order to analyze the efficiency of alternative regulatory environments, we define a measure of the bank's economic value-added. As a simplification, the bank is assumed to capture entirely the economic value-added from its investment and deposit 
activities. That is, the bank's profits from deposit-taking mirror the depositor welfare gains generated from transactions accounts and the bank's asset portfolio NPV reflects the entire NPV produced by its investment activities. This avoids modeling the production functions, utility functions, and bargaining positions of the bank's counter-parties when constructing a measure of social welfare. We also avoid having to explicitly model the components of the bank's franchise value, $J$, by assuming that it entirely reflects economic value-added (e.g., the future NPV of lending opportunities, providing deposit liquidity services, with no net insurance value).

Netted against these economic value-added components are the bank's deadweight equity issuance costs and distress costs, and the dead-weight costs borne by the insurer if the bank is closed. Under insolvency, the insurer pays off depositors with the realized cash flow from the bank's investments, the sale of the bank's franchise, and a drawdown on its cash reserve from accumulated premium payments. Dead-weight closure costs arise if, in disposing of the bank's franchise, the insurer losses a fraction of the initial value $J$. While the magnitude of such losses is unclear in practice, the simplest approach is to assume this fraction is the same as the fraction of franchise value lost by shareholders in a distress situation, $d_{1} \cdot{ }^{12}$ Under this assumption, the insurer's dead-weight closure costs are $d_{1} J$. Aggregating across all of the bank's claimants the realized end-of-period payments (pay-outs), taking their risk-adjusted present expected values, and subtracting initial investment outlays yields the bank's economic value-added. For the special case where closure costs are equal to $d_{1} J$, the bank's economic value-added (EVA) is, ${ }^{13}$

\footnotetext{
${ }^{12}$ See James (1991) for a description and estimates of bank closure costs.

${ }^{13}$ See appendix for a derivation. This measure is consistent with the micro-based approach used in the literature to evaluate efficiency characteristics of bank regulatory policies and it is a variant of formal welfare measures employed in some studies (e.g., Giammarino, Lewis, and Sappington (1993)). However, it is a partial equilibrium approach which takes as given market required rates of return on investments. It is therefore limited as a measure of social optimality when bank regulatory policies affect the activities of all banks and alter the market equilibrium. Macro-based analyses of banks and the role of deposit insurance (e.g., Diamond and Dybvig (1983)) consider the effects on market equilibrium of different banking structures but these models abstract from details important
} 


$$
\mathrm{EVA}=j_{L 0}-I+\pi B e^{-r}+J e^{r}-\frac{d_{0}}{1-d_{0}} E-\frac{d_{1}}{1-d_{1}}\left(P_{D}-P_{I}\right)
$$

\section{Regulatory Policy with Perfect Access to Capital Markets}

This section analyzes optimal bank behavior and the design of regulatory policy under the assumption that the bank has perfect access to capital markets. That is, there are no equity issuance costs, and that the bank has unrestricted access to $0 \mathrm{NPV}$ securities with any desired set of risk characteristics, including a risk-free and an unbounded (infinite) risk security.

\subsection{Fixed-Rate Deposit Insurance}

Under the "perfect capital market access" assumptions described above, if deposit insurance rates $(\phi)$ are fixed, while a wide range of investments and capital structures are possible, any optimal bank operating policy will generate a share value that is equivalent to the value produced by one of three core strategies. Thus a bank's optimization problem can be reduced to choosing the member of the core strategy set that generates the largest share value. Theorem 1 characterizes these three core strategies.

Theorem 1 Assume a bank has unrestricted access to 0 NPV market-traded securities that include a risk-free and an unbounded risk security, zero equity issuance costs $\left(d_{0}, d_{1}=0\right)$, and a positive return on insured deposits $(\pi-\phi \geq 0)$. The bank's optimal choices are equivalent to a strategy whose share value is equal to the maximum of the following three: (i) a default-free strategy in which insured deposits are invested in 0 NPV risk-free securities and all positive NPV loan opportunities are financed with equity; (ii) a maximum risk strategy in which the bank has no equity capital and invests

at the regulatory level, such as bank moral hazard problems and heterogeneous banks. 
all insured deposits in a 0 NPV market-traded security with unbounded risk; (iii) a strategy with an intermediate level of risk that consists of a selection of positive NPV loans and an investment in a 0 NPV market-traded security with unbounded risk. ${ }^{14}$

The first core strategy described in Theorem 1 maximizes the bank's loan portfolio NPV and makes the bank free of default risk. Under this strategy, deposit insurance is worthless. The second core strategy maximizes the deposit insurance value by eliminating equity capital, positive NPV loans, and investing all deposit-generated revenues in the maximum risk 0 NPV security. The third core strategy seeks to gain value by simultaneously taking positive NPV loans and exploiting as much as possible the deposit insurance guarantee by investing in a market-traded security with unbounded risk. Under this strategy, a strategy more likely to be optimal when a bank's loan opportunity set includes positive NPV loans with high risk, the deposit insurance guarantee may have an intermediate value that is substantially less than the asymptotic value reached under the second core strategy. The bank chooses the core strategy that generates the maximum net share value.

An optimal strategy must strike a balance between the shareholder value it generates from positive NPV loans and the value that can be created by exploiting the deposit insurance guarantee. While undertaking positive NPV loans adds directly to shareholder value, other things equal, adding a positive NPV investment reduces the bank's ability to exploit its insurance guarantee. This leads to the following proposition:

Proposition 1 Under fixed-rate deposit insurance, even if a bank has unrestricted access to 0 NPV market-traded securities with any desired risk profile and faces zero equity issuance and distress costs, the bank's optimal investments and capital structure will depend on the characteristics of its loan investment opportunity set.

\footnotetext{
${ }^{14}$ The theorem, other propositions, and corollaries are proven in the Appendix.
} 
There are two special cases in which a bank's optimal strategy and deposit insurance value will be independent of the characteristics of the loan investment opportunity set. The first case is when bank owners can costlessly spin-off positive NPV loan investment opportunities into a separate business structure whose assets are not subject to deposit insurer claims. In the second case, the bank has access only to non-positive NPV loan opportunities and so bank shareholders need not forego making positive NPV loan opportunities in order to generate maximum deposit insurance value. In either of these special cases, the bank will restrict its investments to $0 \mathrm{NPV}$ securities and the bank's optimizing risk exposure choice will be a corner solution. It will pursue a maximum risk strategy if the bank franchise value is sufficiently small; otherwise it will pursue a safe strategy. The conditions determining the bank's choices are stated in the following corollary.

Corollary 1 Under the perfect capital market access conditions of Proposition 1, if bank owners can costlessly shift the bank's positive NPV loan investment opportunities into a separate business structure whose assets are not subject to deposit insurer claims, or if the bank's loan opportunity set contains no positive NPV loans, then the optimal bank risk-taking strategy will be a corner solution. The bank will choose the maximum risk strategy if maximum deposit issuance $(\bar{B})$ exceeds the bank's franchise value $(J)$; otherwise the bank will choose to operate free of default risk.

Many studies have analyzed the effects of bank regulation in models where banks make only 0 NPV investments. One set of these models excludes bank franchise value and, absent regulatory constraints, banks maximize their deposit insurance value by taking maximum risk and leverage (e.g., Furlong and Keeley (1989), Gjerde and Semmen (1995)). Marcus (1984) amends this model by assuming that the bank also has a franchise value. In his model, if end-of-period book assets (assets excluding franchise value) are less than deposit obligations, the insurer closes the bank and the shareholders forfeit the franchise value. As a consequence, a bank's optimal risk 
exposure will depend on the size of its franchise value and the bank will tend toward a polar strategy of either high or low risk. The conditions for Corollary 1 show the specialty of these conclusions. ${ }^{15}$

While Corollary 1 entertains the possibility of an equilibrium dominated by equitysupported finance companies and non-lending insured depository institutions, bank charter policy and regulatory restrictions may preclude this possibility. ${ }^{16}$ Aside from regulatory and charter restrictions, there may be economic reasons for keeping or originating positive NPV loan opportunities in the bank. These may include complementarities with deposit-taking (Fama (1985)) and costs of transferring loan investment opportunities to an outside financing source.

Excepting the special cases of Corollary 1, Proposition 1 establishes that even when banks have perfect access to risk-free and unbounded-risk securities and no capital regulation, the characteristics of a bank's loan investment opportunity set determine its optimal strategy, and a corner solution or any intermediate risk-exposure profile between maximum and minimum default risk is theoretically possible. With fixed rate deposit insurance and positive NPV loan investment opportunities, Proposition 1 implies that a bank may forego some or all of its positive NPV lending opportunities in order to increase the value of its deposit insurance guarantee. This

\footnotetext{
${ }^{15}$ There is also a subtle distinction between our corner solution and that of Marcus. His result implicitly assumes shareholders face distress costs (i.e., $d_{1}=1$ ) whereas we show that, even with no distress costs $\left(d_{1}=0\right)$, the franchise value matters in determining the corner solution (see the proof for Corollary 1).

${ }^{16}$ The Bank Holding Company Act (1956) [BHCA] defines a bank to be an institution that holds demand deposits and makes business loans. While some "nonbanks" -institutions that take insured deposits without making loans - have been created to avoid regulation under the BHCA, the Competitive Equality Banking Act (1987) [CEBA] prohibited the formation of any new unregulated "nonbank" deposit-issuing institutions. While the BHCA and CEBA statutes define the scope of bank regulatory jurisdiction, it is unclear whether bank regulators require a regulated bank to make loans as a condition of maintaining a bank charter. The Community Reinvestment Act (1977) has a minimum lending provision, although it may be possible to circumvent this requirement and claim that the bank satisfies its community service obligation by providing deposit-taking services in targeted communities or investing in market-traded securities backed by low-income mortgages. The so-called "source of strength doctrine" also inhibits the shifting of net firm value to nonbank affiliates. This doctrine requires that the capital of nonbank affiliates in a bank holding company structure be available as a source of support for the bank.
} 
possibility identifies a social cost of fixed-rate deposit insurance.

Corollary 2 Under the capital market access conditions of Proposition 1, the provision of fixed rate deposit insurance may distort a bank's incentives so that it does not choose to invest in the socially optimal loan portfolio (all positive NPV loan opportunities).

Gennotte and Pyle (1991), Chan, Greenbaum, and Thakor (1992), John, John, and Senbet (1991) and Craine (1995), among others, model loans as positive NPV opportunities and conclude that fixed rate deposit insurance induces banks to overinvest in risky loans. All the aforementioned models assume that a bank's total loan portfolio NPV (expected return) is a concave function of portfolio risk. In these models banks increase their risk by accepting marginal loans with declining NPV. Beyond some risk threshold, the bank must accept negative NPV loans. With fixed deposit insurance rates, a bank will lend until the increase in the insurance subsidy is exactly offset by the decrease in the loan portfolio NPV for marginal increases in portfolio risk. Thus, from a social standpoint, there is over-investment in bank lending in these models. ${ }^{17}$

As discussed earlier, the assumed concave NPV-risk relationship which drives the over-investment result is not based on any equilibrium condition or formal empirical evidence. Moreover, the result also depends on the exclusion of risky 0 NPV market-traded securities from a bank's investment opportunity set. Even retaining the concave loan NPV and risk relation, the possibility of investing in sufficiently risky 0 NPV securities would make the bank's NPV-risk relationship a quasi-concave function, and the bank would not need to invest in negative NPV loans to exploit its insurance guarantee. ${ }^{18}$ This result is proved in the Appendix (Corollary 4).

\footnotetext{
${ }^{17}$ See Gennotte and Pyle (1991). This also is Chan, Greenbaum, and Thakor's "distortions induced by moral hazard" (p. 236) and Craine's "agency cost of debt" (p. 1740).

${ }^{18}$ For example, in the Gennotte and Pyle model, if $J^{\prime}(v, \sigma)$ represents the modified opportunity set, for large $v$ and large $\sigma, \frac{\partial J^{\prime}(v, \sigma)}{\partial v}=0$, and $\frac{\partial J^{\prime}(v, \sigma)}{\partial \sigma}=0$.
} 
Our argument on the lending inefficiency induced by fixed-rate deposit insurance does not depend on an assumed concave relationship between loan portfolio NPV and risk but owes to the fact that positive NPV loan investments limit a bank's ability to raise its deposit insurance value. Deposit-financed positive NPV loans with relatively low risk add relatively little to the bank's portfolio risk, while their positive NPV reduces the bank's debt-to-(market) equity ratio. Augmenting such a loan portfolio with (unbounded) high-risk deposit-financed $0 \mathrm{NPV}$ securities will generate a portfolio with less overall risk than one that consists entirely of high (unbounded) risk securities. Thus banks seeking a high insurance value may forego at least some loans with positive NPV (i.e., adopt strategies (ii) or (iii) in Theorem 1). In contrast to earlier arguments, absent investment constraints, the social inefficiency generated by fixed-rate deposit insurance owes to under-investment in positive NPV bank loans. ${ }^{19}$

\subsection{Fairly-Priced Deposit Insurance}

We now consider the characteristics and possibility of fairly-priced deposit insurance when initial equity issuance costs are zero $\left(d_{0}=0\right)$. Deposit insurance is said to be fairly-priced if the insurance premium is equal to the value of deposit insurance to bank shareholders, i.e., $\phi B e^{-r}=P_{I}{ }^{20}$ Under a fair-pricing assumption, the bank's optimal behavior is summarized in the following proposition.

Proposition 2 If (i) initial equity issuance is costless $\left(d_{0}=0\right)$, (ii) the bank has unrestricted access to risk-free bond investments, (iii) deposit-taking is profitable ( $\pi \geq$ 0 ), and (iv) deposit insurance is fairly priced, bank net shareholder value is maximized

\footnotetext{
${ }^{19}$ The under-investment result is related to Meyer's (1977) argument that, in the presence risky debt, owners may forego positive NPV investments that increase firm value to the benefit of debtholders but at the expense of shareholders. In the present case, positive NPV loan investments would add to firm value but might cost shareholders more in terms of foregone insurance (option) value.

${ }^{20}$ The value of the insurance as an asset to shareholders will not equal its value as a liability to the insurer unless the insurer's franchise liquidation costs equal the distress equity issuance costs to shareholders (see section 2.4).
} 
by choosing all positive NPV loans and accepting all insured deposits.

When insurance is fairly priced and the capital market access conditions of Proposition 2 prevail, if there are no costs to financial distress $\left(d_{1}=0\right)$, then a bank's choice of a capital structure is irrelevant provided that all profitable investments are funded. When there are distress costs $\left(d_{1}>0\right)$, the bank's capital structure choice may have additional implications for shareholder value. Issuing equity and purchasing risk-free bonds may add to shareholder value by reducing the expected costs of financial distress. When $d_{0}=0$, the risk-adjusted cost of financing a risk-free bond position is the risk-free rate while the bonds may earn shareholders a higher rate of return by eliminating the possibility of costly financial distress. ${ }^{21}$ When insurance is fairly priced and initial equity issuance is costless, an optimal bank strategy is to set $T=\bar{B} e^{-r}$ and operate free of distress risk. We write this result as a corollary to Proposition 2:

Corollary 3 If deposit insurance is fairly priced and the bank faces positive financial distress costs $\left(d_{1}>0\right)$ and no costs for issuing outside equity in non-distress periods $\left(d_{0}=0\right)$, the bank will operate free of default risk.

Karekan and Wallace (1978) derive a result analogous to Corollary 3 in a statespace model in which a bank faces fairly-priced insurance, no costs of equity issuance, and an investment opportunity set that contains 0 NPV complete contingent claims. Corollary 3 shows that their result generalizes under the weaker conditions that the bank's investment opportunity set includes only (potentially positive NPV) loans and risk-free bonds.

When an intermediary can guarantee transaction account payment obligations by collateralizing them with risk-free bonds, if outside equity issuance is costless, the potential for costless collateralization creates the possibility of implementing fairly-

\footnotetext{
${ }^{21}$ It is also possible to collateralize deposits with 0 NPV risky securities. See the proof of theorem 1 in the appendix.
} 
priced deposit insurance without any governmental subsidy to the banking system. This possibility is formalized in Proposition 3.

Proposition 3 If (i) initial equity issuance is costless $\left(d_{0}=0\right.$ ) and, (ii) the bank has unrestricted access to risk-free bond investments, then a bank is indifferent between: (1) fairly-priced deposit insurance, and (2) a requirement that all insured deposits be collateralized with risk-free bond investments with an insurance premium equal to 0.

Proposition 3 establishes the possibility of a fairly-priced deposit insurance system in the form of a "narrow bank" deposit collateralization requirement. This proposition does not depend on banks earning deposit rents since, in a competitive equilibrium, banks still will issue the amount of deposits that depositors wish to hold. Proposition 3 does, however, require that banks can issue equity at competitive risk-adjusted rates with no costs or discounts generated by moral hazard or informational asymmetries.

While virtually transparent in this model setting, Proposition 3 is inconsistent with earlier arguments that risk-sensitive deposit insurance premiums are impossible without some form of deposit-related bank subsidy or rent (Buser, Chen, and Kane (1981), Chan, Greenbaum, and Thakor (1992), Craine (1995)). The inconsistency arises from different assumptions on banks' access to 0 NPV market-traded securities. Both Chan, Greenbaum, and Thakor (1992) and Craine (1995) assume that banks face no equity issuance costs but restrict bank portfolios to private-information loans. In both models, an incentive-enhanced deposit insurance contract is needed to implement a risk-sensitive pricing policy but an incentive-compatible contract requires that the bank earn rents on its deposits. Chan, Greenbaum, and Thakor (1992) conclude that, without deposit rents (or some deposit-related subsidy), fairly-priced deposit insurance is not possible.

Craine (1995) argues that current bank charter policy restricts the issuance of transactions accounts which enables banks to earn rents on insured deposits. While deposit rents make fairly-priced insurance possible, the deposit rents also support an 
inefficient (over-investment) lending program (Craine's Proposition 1). Craine's solution is to change bank charter policy to permit firms that invest in public-information 0 NPV securities to issue transactions accounts. For these firms, Craine argues that fairly-priced insurance is possible without deposit rents or subsidies since the insurer can directly observe the market values of the firm's assets. In Craine's model, deposit rents would be competed away and transactions accounts would only be issued by "public-information" intermediaries. Private-information intermediaries would be equity financed and operate efficiently (his Proposition 2).

In both the Craine and the Chan, Greenbaum, and Thakor models, if bank investment opportunity sets were to include risk-free bond investments, our Propositions 2 and 3 apply directly and: (i) banks would issue deposits according to depositors' demands and would make efficient lending decisions regardless of charter policy restrictions (or lack thereof) on the right to issue deposit accounts (Proposition 2) and, (ii) fairly-priced insurance could prevail in equilibrium (Proposition 3). When outside equity issuance is costless as it is in these models, deposit collateralization is costless, and the "narrow bank" equilibrium is feasible and eliminates the moral hazard distortions of fixed-rate deposit insurance. ${ }^{22}$

\section{Regulatory Policy when Equity Issuance is Costly}

When it is costly to issue outside equity, a narrow banking requirement can generate significant social costs in the form of equity issuance costs and the opportunity cost of positive NPV investments that go unfunded. The latter cost is a true social cost only if banks play a unique role among financial institutions and thereby have monopoly

\footnotetext{
${ }^{22}$ In these models, as well as our own, market interest rates and equilibrium required rates of return on risky investments are exogenous. In this context, the narrow banking solution is socially costless when equity issuance is costless. In a broader context, however, the optimality of a narrow banking policy will depend on how it affects interest rates and equilibrium required rates of return on risky assets. While Diamond and Dybvig (1986) argue that these general equilibrium effects may be significant, Merton and Bodie (1993) disagree.
} 
access to investment opportunities that go unfunded in the new equilibrium. Such costs reduce the appeal of a strict narrow banking policy.

Absent a narrow bank policy, pricing the deposit insurance guarantee is fraught with difficulties. One difficultly is that the bank regulators are unlikely to have sufficient expertise to value the bank's (non-traded) assets or assess their risk. ${ }^{23}$ Even if regulators have sufficient expertise, the bank has an incentive to disguise high-risk investments or substitute into high risk assets after its insurance premium has been set. Without resorting to intensive and highly intrusive monitoring, the moral hazard problem necessitates capital or other regulations that reduce risk-taking incentives arising from the deposit guarantee. The analysis here assumes that the insurer has the expertise to value individual assets banks might acquire and examines alternative capital-based regulatory policies intended to solve the moral hazard problem.

To facilitate the analysis, we consider a hypothetical banking system comprised of four banks. Each bank faces a unique loan investment opportunity set consisting of three possible loans (7 possible loan combinations). Individual loans have log-normal end-of-period payoffs that include a single systematic (priced) risk source and an idiosyncratic risk component. Banks' individual loan opportunity sets are described in Table 1. Bank A's opportunity set includes loans with relatively modest overall risk. Bank B can invest in two loans with relatively high risk, one of which has substantial NPV. Bank C's opportunities also include relatively high risk loans; its most profitable loan has negative systematic risk. Bank D's investment opportunity set includes a large, low risk, high NPV loan, and a large, high risk, 0 NPV loan. All four banks can invest in a risk-free bond and a risky 0 NPV security whose characteristics are described in the last row of Table 1. For simplicity, all heterogeneity across banks is assumed to arise from differences in loan investment opportunities. The three banks are subject to identical equity issuance costs $\left(d_{0}=.2\right)$, distress costs $\left(d_{1}=.4\right)$,

\footnotetext{
${ }^{23}$ Flannery (1991) emphasizes this point and considers the consequences for insurance pricing and bank capital policy, although his analysis does not incorporate moral hazard behavior.
} 
franchise values $(J=40)$, maximum internal equity capital $(W=27)$, maximum deposits $(\bar{B}=200)$ and a common transactions service profit rate $(\pi=0.025)$. The risk-free rate is arbitrarily set at .05 .

\subsection{The First-Best Pricing Solution}

To establish an optimal benchmark, assume that the insurer has sufficient knowledge to set a fair insurance premium and that the bank must irrevocably commit to its asset portfolio and capital structure before the insurer sets its premium. Table 2 reports each bank's optimization results. ${ }^{24}$ Columns two through six report optimal loan, securities, and equity financing choices. Net Share Value is defined in equation (3) above. Economic Value-Added is the bank's net social value and here is defined assuming that insurer closure costs mirror bank distress costs (equation (5)). Net Insurance Value, $P_{I}-\phi B e^{-r}$, is zero by construction. For the Risk Capital Ratio, capital is defined as the book value of loans and securities minus deposits, and risk assets are defined as the book value of loans plus the risky security investment. Under our closure cost assumption, if deposit insurance is fairly-priced, $S=E V A$, and maximizing net share value also maximizes economic value-added. By this measure, fairly-priced deposit insurance is an efficient regulatory policy.

Implementing a fairly-priced deposit insurance system is problematic when a bank's decisions cannot be completely and continuously monitored. Although each bank's insurance premium may be calibrated to fair value by assuming a bank operating policy that achieves maximum economic value-added, given this premium and an ability to alter its asset mix, a bank may face incentives to substitute into a more risky asset portfolio. In the example in Table 2, banks B, C and D could

\footnotetext{
${ }^{24}$ The shareholder equity maximization problem is solved numerically using integer programming as described in equation (4) above. As the sum of lognormal variables is not lognormal and does not have a closed form density function, all option values are calculated using numerical techniques. A log-normal distribution approximation to the sum of log-normal variables is used (see Levy (1992) for details). Option values from the use of the log-normal approximating distribution were similar to values calculated using Duan and Simonato's (1995) empirical martingale simulation technique.
} 
Table 1

Alternative Loan Opportunity Sets

\begin{tabular}{|c|c|c|c|c|c|c|}
\hline $\begin{array}{c}\text { loan } \\
\text { number }\end{array}$ & $\begin{array}{c}\text { loan } \\
\text { amount }\end{array}$ & $\begin{array}{l}\text { expected } \\
\operatorname{return}^{a}\end{array}$ & $\begin{array}{c}\text { systematic } \\
\text { (priced) risk }{ }^{b}\end{array}$ & $\begin{array}{c}\text { non-systematic } \\
\text { risk }^{c}\end{array}$ & $\begin{array}{l}\text { total } \\
\text { risk }^{d}\end{array}$ & $\mathrm{NPV}^{e}$ \\
\hline \multicolumn{7}{|c|}{ Loan Opportunity Set A } \\
\hline 1 & 75 & .20 & .08 & .20 & .22 & 5.44 \\
\hline 2 & 50 & .10 & 0 & .45 & .45 & 2.56 \\
\hline 3 & 100 & .25 & .10 & .30 & .32 & 10.52 \\
\hline \multicolumn{7}{|c|}{ Loan Opportunity Set B } \\
\hline 1 & 75 & .30 & .10 & .50 & .51 & 12.14 \\
\hline 2 & 140 & .12 & .05 & .20 & .21 & 2.83 \\
\hline 3 & 50 & .20 & .10 & .60 & .61 & 2.56 \\
\hline \multicolumn{7}{|c|}{ Loan Opportunity Set C } \\
\hline 1 & 75 & .20 & .10 & .45 & .46 & 3.85 \\
\hline 2 & 100 & .03 & -.10 & .35 & .36 & 8.33 \\
\hline 3 & 50 & .21 & .12 & .45 & .47 & 2.04 \\
\hline \multicolumn{7}{|c|}{ Loan Opportunity Set D } \\
\hline 1 & 190 & .21 & .05 & .10 & .11 & 21.30 \\
\hline 2 & 190 & .75 & .70 & .90 & 1.14 & 0.00 \\
\hline 3 & 50 & .21 & .12 & .45 & .47 & 2.04 \\
\hline \multicolumn{7}{|c|}{ Risky Market-Traded Security } \\
\hline & & .35 & .30 & .30 & .42 & 0 \\
\hline \multicolumn{7}{|c|}{$\begin{array}{l}{ }^{a} 1 \text {-period expected return to loan i defined by } \mu_{i}+.5 \sigma_{i}^{2} . \\
{ }^{b} 1 \text {-period systematic risk (standard deviation) for loan i, } s_{0 i} \text {. }\end{array}$} \\
\hline
\end{tabular}

is $1, \lambda=(1,0)$, and $r=.05$ is the risk-free rate. 
Table 2

Fairly-Priced Insurance with Perfect Monitoring

Bank Optimizing Results

\begin{tabular}{llllllllll}
\hline & & & & & & Net & Econ & Net & Risk \\
Bank & Loans & $\begin{array}{l}\text { Risky } \\
\text { Security }\end{array}$ & $\begin{array}{l}\text { Risk-less } \\
\text { Security }\end{array}$ & $\begin{array}{l}\text { Internal } \\
\text { Equity }\end{array}$ & $\begin{array}{l}\text { Outside } \\
\text { Equity }\end{array}$ & $\begin{array}{l}\text { Share } \\
\text { Value }\end{array}$ & $\begin{array}{l}\text { Value- } \\
\text { Added }\end{array}$ & $\begin{array}{l}\text { Insurance } \\
\text { Value }^{a}\end{array}$ & $\begin{array}{l}\text { Capital } \\
\text { Ratio }^{b}\end{array}$ \\
\hline & & & & & & & & & \\
A & $1,2,3$ & 0.00 & 0.00 & 27.00 & 3.47 & 59.33 & 59.33 & 0.00 & .154 \\
B & 1,2 & 0.00 & 5.26 & 27.00 & 0.00 & 55.35 & 55.35 & 0.00 & .140 \\
C & $1,2,3$ & 0.00 & 0.00 & 27.00 & 4.57 & 53.58 & 53.58 & 0.00 & .154 \\
D & 1 & 0.00 & 32.00 & 27.00 & 0.00 & 64.08 & $\underline{64.08}$ & 0.00 & .167 \\
& & & & & & & 232.34 & &
\end{tabular}

\footnotetext{
${ }^{a} P_{I}-\phi B e^{-r}$. For banks $\mathrm{A}, \mathrm{B}, \mathrm{C}$, and $\mathrm{D}$, the fair premium rates are .002, .008, .009, and 0, respectively.

${ }^{b}$ Book capital to risk assets. Book capital equals investments in loans and securities minus deposits. Risk assets equal loans plus risky securities.
}

increase their insurance values, and net shareholder values, if they could substitute into higher risk assets at the given insurance rates (reported in footnote a). The insurance would become under-priced and, while shareholder values would increase, economic value-added would be reduced.

\subsection{The Narrow Banking Solution}

Absent any information about bank investment opportunities, deposit insurance can still be fairly priced by imposing a narrow banking requirement that all deposits be collateralized with Treasury bills. While a narrow banking requirement removes the moral hazard problem, it may entail significant social costs in the form of equity issuance costs and forgone profitable investment opportunities as the cost of financing loans with equity may exceed the loans' value to bank shareholders. Table 3 illustrates these costs for the banks in our hypothetical banking system. The results show that the narrow banking solution lowers substantially the banks' aggregate economic value- 
Table 3

Narrow Banking: 100 Percent Equity for Risk Assets

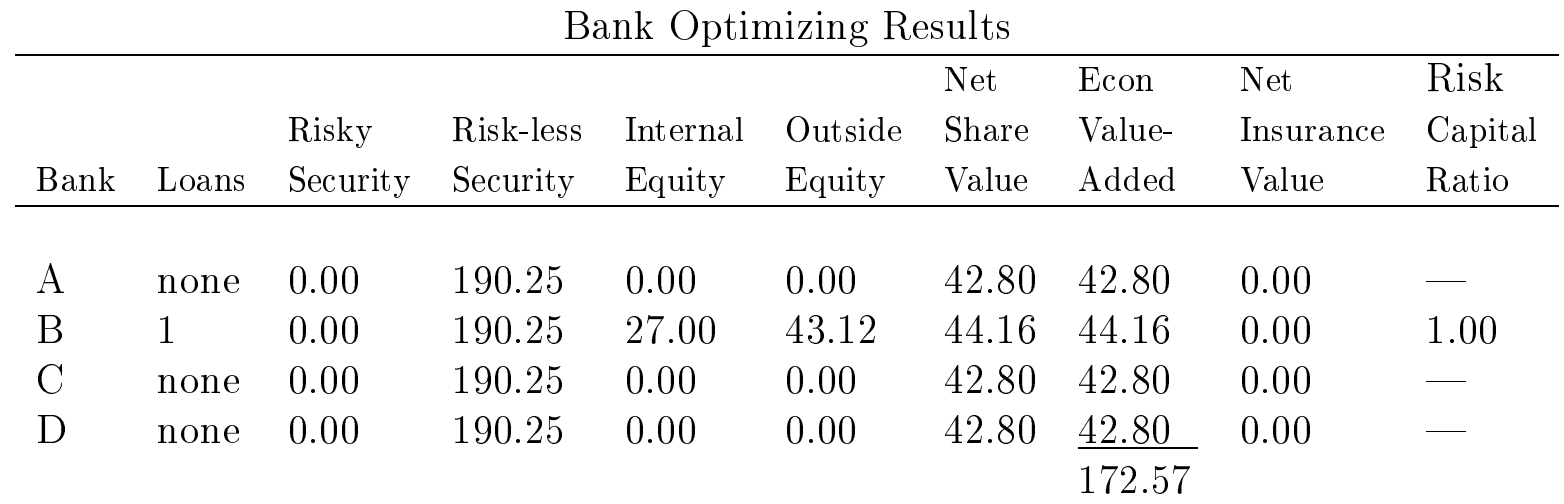

added (by 59.77) when compared to the first-best solution illustrated in Table $2 .{ }^{25}$

\subsection{Fair-Pricing with Capital Requirements}

If the regulator is unable to continuously monitor a bank's investment choices, but has complete information about each bank's investment opportunities and can enforce a minimum capital requirement, moral hazard incentives can be eliminated and fairinsurance premiums can be set at a smaller social cost than is incurred under narrow banking. In imposing on each bank an individually-tailored insurance premium and minimum required capital-to-risk-asset ratio, the regulator must determine the minimum capital requirement and insurance premium rate combination that maximizes the bank's economic value-added, subject to a fair-pricing condition and incentivecompatible condition that the bank have no incentive to engage in asset substitution at its capital requirement and insurance premium settings.

More formally, let $\kappa$ define the minimum required ratio of regulatory capital (book

\footnotetext{
${ }^{25}$ In this and the following illustrations, the banks' opportunity sets continue to be those described in Table 1 and the other parameter values that underly Table 2 are unchanged. This includes the bank franchise value even though, in principle, this value could be expected to depend on the regulatory regime in effect.
} 
value of assets less book value of deposits) to risk assets (book value of loans plus risky securities). Let $O_{i}=\left\{\left(S_{i}^{*}(\phi, \kappa), P_{I_{i}}^{*}(\phi, \kappa)\right) \quad \forall \phi \in[0, \pi], \kappa \in[0,1]\right\}$ represent bank i's set of maximum net share values, $S_{i}^{*}$, and corresponding optimal gross insurance values, $P_{I_{i}}^{*}$, for admissible insurance premiums and minimum capital ratios $(\phi, \kappa)$, under the assumption that the regulator cannot monitor the risk of the bank's

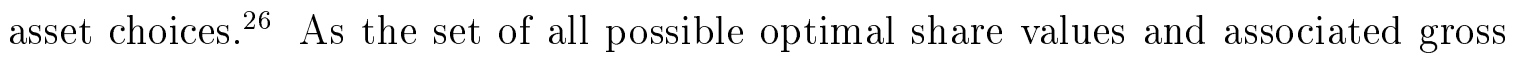
insurance values, $O_{i}$ is not restricted to fair premium solutions. That is, $S_{i}^{*}$ includes any increment in net share value generated by asset substitution.

Let $F_{i}=\left\{(\phi, \kappa) \mid P_{I_{i}}^{*}(\phi, \kappa)=\phi \overline{B_{i}}\right\} . F_{i}$ is the set of all insurance premium and capital requirement pairs that are consistent with share value maximization and a fair insurance pricing solution for bank i. Members of $F_{i}$ are the subset of $O_{i}$ that satisfy the incentive compatibility condition. Since $S_{i}$ coincides with EVA when insurance is fairly priced, maximizing $S_{i}$ maximizes EVA. The regulator's policy problem can be formally stated as,

$$
\operatorname{Max}_{(\phi, \kappa)}\left\{S_{i}^{*}(\phi, \kappa) \mid(\kappa, \phi)_{i} \in F_{i}, \forall i\right\}
$$

If $F_{i}$ is non-empty, a fair-insurance pricing result can be achieved without complete monitoring. A 100 percent equity-to-risk asset ratio (with $\phi=0$ ) will always be an element of $F_{i}$. While the optimal minimum capital requirement generally is less severe than a narrow banking requirement, it may still generate social costs. That is, if the incentive compatibility condition is binding, the first-best capital and insurance premiums (Table 2) will not belong to $F_{i}$ and share value and EVA will be less than in the first-best solution. It is also clear from the formal statement of the problem that the regulator must have information on bank investment opportunity sets equivalent to that of bank insiders in order to construct the optimal $(\phi, \kappa)$ pair for each bank.

\footnotetext{
${ }^{26}$ The ranges for insurance premium and capital requirement settings, $\phi \in[0, \pi], \kappa \in[0,1]$, ensure that each bank finds it optimal to issue its maximum amount of insured deposits.
} 
Table 4

Optimal Bank-Specific Capital Requirements and Fair Insurance Rates Without Perfect Monitoring

\begin{tabular}{cccccc} 
Bank & $\begin{array}{c}\text { Required } \\
\text { Risk-Capital } \\
\text { Ratio }\end{array}$ & $\begin{array}{c}\text { Premium } \\
\text { Rate }\end{array}$ & $\begin{array}{c}\text { Economic } \\
\text { Value-Added }\end{array}$ & $\begin{array}{c}\text { First-Best } \\
\text { Economic } \\
\text { Value-Added }^{a}\end{array}$ & $\begin{array}{c}\text { Net } \\
\text { Insurance } \\
\text { Value }\end{array}$ \\
\hline $\mathrm{A}^{b}$ & $\geq .154$ & .002 & 59.33 & 59.33 & 0.00 \\
$\mathrm{~B}$ & $\geq .247$ & .005 & 55.30 & 55.35 & 0.00 \\
$\mathrm{C}^{c}$ & $\geq .154$ & .009 & 53.58 & 53.58 & 0.00 \\
$\mathrm{D}$ & $\geq .351$ & .000 & $\underline{55.36}$ & $\underline{64.08}$ & 0.00
\end{tabular}

${ }^{a}$ Taken from Table 2.

${ }^{b} \mathrm{~A}$ 's optimal strategy for any minimum required risk-capital ratio between 0 and .154 .

${ }^{c} \mathrm{C}$ 's optimal strategy for any minimum required risk-capital ratio between .045 and .154 .

The second and third columns in Table 4 present bank-specific minimum capital requirements and fair-premium rates that solve equation (6) for the four banks in our hypothetical example. The fourth column shows the maximum economic value-added for each bank and, for comparison, the fifth column shows the first-best economic value-added reported in Table 2 . The minimum capital requirements remove the moral hazard incentives for bank's B, C, and D that would exist at first-best capital requirements and premium rates. The costs of imposing the capital requirements are a small reduction in bank B's EVA due to a reduced loan portfolio NPV and equity issuance costs incurred by bank D.

Notice that the costs associated with a minimum risk-asset capital standard regime do not include a loss in the value of "liquidity services." Because the capital requirement applies to risk assets defined to exclude an identifiable risk-free asset (e.g., Treasury bills), there is no incentive for banks to reduce deposit levels. This result 
contrasts with studies that suggest an important cost of more stringent capital requirements is a reduction in the provision of socially valuable liquidity services (e.g., John, John, and Senbet (1991), Campbell, Chan, and Marino (1992), Giammarino, Lewis and Sappington (1993)). With an identifiable 0 NPV risk-free security, there is no need for deposit reductions if capital requirements are defined to exclude investments in the risk-free security. ${ }^{27}$

The possibility of using a risk-asset capital requirement to control moral hazard incentives bears on the debate concerning the ability of bank capital requirements to limit the insurer's liability. First we note that, for banks where investment opportunities include only 0 NPV assets, a narrow bank deposit collateralization requirement completely removes the moral hazard problem without diminishing the bank's economic value-added. ${ }^{28}$ When banks' investment opportunities also include positive NPV non-traded bank loans, risk-asset capital requirements can control moral hazard but may generate economic costs when equity issuance is costly. In contrast to our results, Gennotte and Pyle (1991) find that a more stringent (leverage) capital requirement may induce a bank to shrink its size and increase its asset risk sufficiently to raise the probability of bank failure.

These seemingly contradictory results on the efficacy of capital regulations can be reconciled. The optimal capital requirements that eliminate moral hazard incentives are bank-specific and thus must be tailored to the characteristics of individual banks' investment opportunity sets and other bank-specific information. ${ }^{29}$ Studies such as Gennotte and Pyle consider arbitrary increases in capital requirements under highly

\footnotetext{
${ }^{27}$ Gjerde and Semmen (1995) also recognize this point.

${ }^{28}$ This holds regardless of whether the bank maximizes a shareholder utility function as in Kim and Santomero (1988b) or Rochet (1992), or shareholder value as in Keeley and Furlong (1991) or Gjerde and Semmen (1995).

${ }^{29}$ While a 100 percent capital requirement against risk assets always will eliminate moral hazard incentives, Gennotte and Pyle overlook this perhaps because they only consider capital requirements defined in terms of a leverage constraint. When defined this way, a bank that has no leverage (i.e., no deposits) is not a bank in the traditional sense. John, Saunders, and Senbet (1995) also claim that in some instances capital requirements may be unable to remove the moral hazard incentive. Again, they are mislead because they concentrate on a leverage ratio capital requirement.
} 
specialized investment opportunity sets. For specialized investment opportunity sets and other conditions, arbitrary increases in bank capital requirements may induce a bank to increase its asset risk and insurance value because optimal asset risk is not necessarily monotonically declining in the required capital ratio (defined either as a leverage or a risk-asset capital requirement). This result is formally stated and proved in Proposition 4 in the appendix.

\subsection{Separating Incentive-Compatible Contracts}

The design of an optimal bank-specific capital policy imposes the unrealistic requirement that the regulator know each bank's investment opportunity set. A growing literature has proposed the use of incentive-compatible contracting mechanisms that can simultaneously identify the investment opportunity sets specific to individual banks and control moral hazard behavior even when the regulator is not fully informed a priori. Kim and Santomero (1988a), John, John, and Senbet (1991), Chan, Greenbaum, and Thakor (1992), Campbell, Chan, and Marino (1992), Giammarino, Lewis, and Sappington (1993), and John, Saunders and Senbet (1995), among others, provide formal analyses of incentive-compatible policies.

Incentive-compatible policies have been proposed based on banks' initial actions (ex ante) and on bank return realizations (ex post). For ex ante approaches, the regulator provides banks with a menu of "contracts" each of which consists of a different set of terms. The set of terms selected by a bank reveals its "risk-type" and the contract terms control the bank's moral hazard incentives and can provide for riskbased insurance premiums. In the stylized models used, the regulator constructs the incentive-compatible contract menu based on a known distribution of possible values for a parameter (or parameters) that completely characterizes a bank's investment opportunity set. The distribution of parameter values represents the cross-section of investment opportunities faced by all regulated banks. Asymmetric information prevails and only the individual bank observes its actual parameter value(s). 
In the spirit of this approach, assume as before that there are four banks each with a loan investment opportunity set that is one of the types presented in Table 1, either A, B, C, or D. While an individual bank knows its type, the regulator only knows the characteristics of the alternative investment opportunity sets but does not know the opportunity set associated with each individual bank. Because it cannot distinguish bank types, the regulator cannot directly set the bank specific capital requirements and insurance premiums that achieve the results in Table 4, i.e., that solve the policy problem in expression (6). The incentive-compatible literature suggests, however, that the risk-types can be identified by an appropriate set of contracts.

Consider, as in Chan, Greenbaum, and Thakor (1992), an ex ante incentivecompatible policy based on a menu of contracts whose terms consist of combinations of a required minimum capital ratio and insurance premium rate, assuming the regulator can enforce a minimum capital requirement. Formally, let $G=\left\{(\phi, \kappa)_{j}\right\}$ be the menu of required capital ratio and insurance premium combinations offered. Let $S_{i}^{*}\left((\phi, \kappa)_{j}\right)$ and $P_{I_{i}}^{*}\left((\phi, \kappa)_{j}\right)$ represent respectively bank i's maximum net share value and corresponding gross deposit insurance value conditional on selecting contract $\mathrm{j}$ from the menu G. Under a fair pricing condition, each element in $G$ must be an element in at least one bank's $F_{i}, \forall i$, where $F_{i}$ is the set of all insurance premium and capital requirement pairs that are consistent with share value maximization and fairly-valued insurance for bank $i$. In contrast to the previous problem, the regulator cannot directly impose contract terms on bank $i$ since the regulator cannot distinguish among banks. The menu of contract terms offered, therefore, must meet the additional incentive compatibility condition that bank $i$ will prefer a set of contract terms that is an element of $F_{i}$ to all other contract terms. The regulator's problem then is to develop the menu of contracts terms that maximize each individual bank's share values subject to fair insurance premium rates and the incentive compatibility 
conditions. This can be written as ${ }^{30}$

$$
\begin{array}{r}
\operatorname{Max}_{G}\left\{S_{i}^{*}\left((\phi, \kappa)_{i}\right) \mid G \ni(\kappa, \phi)_{i} \in F_{i}, \forall i\right\} \\
\text { subject to } S_{i}^{*}\left((\phi, \kappa)_{i}\right) \geq S_{i}^{*}\left((\phi, \kappa)_{j}\right), \\
\text { for } G \ni(\phi, \kappa)_{j} \in F_{j} \quad \forall j \neq i .
\end{array}
$$

In general, the capital requirements and premium rates that solve the policy problem when the regulator is not fully informed about individual bank investment opportunities ((expression (7)) will differ from those that solve the policy problem where the regulator is fully informed as to opportunity sets but cannot continuously monitor (expression (6)). For example, if banks were offered a menu of contract terms taken from columns 1 and 2 of Table 4 -the capital requirements and premium rate combinations that maximize firm values under the full information assumption-bank optimizing choices would not identify their types. Given such a menu, all banks would claim to have a type A investment opportunity set.

If bank $\mathrm{A}$ is excluded from the illustration, the fair-pricing contract terms for the remaining banks in Table 4 show a monotonic inverse relationship between the contract's capital requirement and its insurance premium. The inverse relationship is consistent with the ordering of terms proposed by Chan, Greenbaum and Thakor as an incentive compatible policy when the regulator is not completely informed on banks' specific investment opportunity sets. This inverse relationship will not, however, produce a correct sorting of banks in our illustration as type B and D banks would reveal themselves to be type $\mathrm{C}$ banks. They would choose higher risk investments and produce lower EVA than the full information results presented in Table 4 and their insurance would be under-priced.

\footnotetext{
${ }^{30}$ The ranges for $\kappa$ and $\phi \forall i$ are subject to the same restrictions imposed in problem (6) to ensure banks issue deposits and thus "participate" in the deposit insurance program. Also, in this formulation, as well as in (6), the maximization of individual bank share values coincides with the maximization of the sum of share values across banks.
} 
Table 5

Optimal Incentive-Compatible Capital Requirements and Fair Insurance Rates

With Incomplete Information

\begin{tabular}{|c|c|c|c|c|c|}
\hline Bank & $\begin{array}{c}\text { Required } \\
\text { Risk-Capital } \\
\text { Ratio }^{a} \\
\end{array}$ & $\begin{array}{l}\text { Premium } \\
\text { Rate }\end{array}$ & $\begin{array}{c}\text { Economic } \\
\text { Value-Added }\end{array}$ & $\begin{array}{c}\text { First-Best } \\
\text { Economic } \\
\text { Value-Added }^{b}\end{array}$ & $\begin{array}{c}\text { Net } \\
\text { Insurance } \\
\text { Value } \\
\end{array}$ \\
\hline A & $\geq .351$ & 0 & 52.17 & 59.33 & 0.00 \\
\hline B & $\geq 351$ & 0 & 54.16 & 55.35 & 0.00 \\
\hline $\mathrm{C}$ & $\geq .351$ & 0 & 49.59 & 53.58 & 0.00 \\
\hline $\mathrm{D}$ & $\geq .351$ & 0 & $\frac{55.36}{211.28}$ & $\frac{64.08}{232.34}$ & 0.00 \\
\hline
\end{tabular}

${ }^{a}$ Banks A, C, and D will optimally operate at the minimum required capital ratio. Bank B will optimally choose to operate at a capital ratio of .423.

${ }^{b}$ Taken from Table 2.

The formal solution to the incentive-compatible contracting problem is given in Table 5. The optimal incentive-compatible contact imposes a uniform minimum riskasset capital requirement and a uniform insurance premium on all banks. A result is that bank EVAs are mostly smaller than those presented in Table 4. In general, this occurs because more limited information imposes additional incentive-compatibility conditions on the regulator which constrains further the set of feasible policies from which to choose. Given the bank investment opportunities (and equity issuance costs) in this example, the incentive-compatible policy even fails to distinguish banks.

Chan, Greenbaum, and Thakor type contracts fail to generate a separating equilibrium in this example because our investment opportunity set and financing structures are more complex than those that underlie their model. By assumption all bank loan investment opportunities sets in Chan, Greenbaum, and Thakor can be ranked ac- 
cording to first-order or second-order stochastic dominance. ${ }^{31}$ In our model, the set of possible asset portfolios represent investment opportunities whose combinations of risk, NPV, and financing requirements do not fit any well-defined risk ordering. In particular, the opportunity sets cannot be uniquely ordered by a one-dimensional risk measure such as first- or second-order stochastic dominance.

The prior example clearly shows that the design and economic efficiency of incentivecompatible contracts depends importantly on the characteristics of bank investment opportunity sets. The existing literature has not recognized this importance. Moreover, properly designing incentive contracts also depends on bank-specific parameters other than the investment opportunity set. For example, incentive-compatible contract terms would depend on equity financing $\operatorname{costs}^{32}$ Allowing for realistic bank investment opportunity sets, the design of incentive-compatible policies that achieve a high degree of sorting among bank types will impose formidable information requirements on the regulator. Theoretical modeling assumptions to the contrary, bank regulators are unlikely to have a clear idea of the possible sets of investment opportunities available to individual banks. ${ }^{33}$ If the regulator does not not know the distribution of potential bank investment opportunity sets, it may not be possible to design separating incentive-compatible contracts. Not only may an incorrectly constructed menu of contract terms result in insurance mispricing and lost social welfare, it may also be inferior to outcomes that may be achievable under fixed price insurance and simpler minimum capital rules.

The efficiency of ex post incentive-compatible contracting mechanisms is likely to be subject to information limitations similar to those that ex ante contracts are

\footnotetext{
${ }^{31}$ This rank ordering is also assumed in Giammarino, Lewis and Sappington (1992), John, John and Senbet (1991), and John, Saunders and Senbet (1995).

${ }^{32}$ In Chan, Greenbaum, and Thakor (1992) equity issuance costs are assumed to be zero (in Giammarino, Lewis, and Sappington (1993) they are homogeneous across banks).

${ }^{33}$ This information requirement goes substantially beyond being able to itemize different types of loans and other investments that banks might make. It requires delimiting the sets of investments that individual banks might be able to put together.
} 
subject to. Assuming that banks' realized returns are observable, John, John, and Senbet (1991) propose a performance-based policy under pre-set deposit insurance premium rates. To remove incentives for a bank to take on high-risk, negative NPV investments, John, John, and Senbet would impose a special tax on high net returns earned by a bank, a subsidy at lower returns, and allow deductibility of debt costs to encourage deposit financing. ${ }^{34}$ If the tax and subsidy scheme is to promote efficient investment, the threshold return level at which to apply the high tax rate must be set to account for the distribution of possible loan opportunities that individual banks might face. Without knowing this distribution, the regulator cannot correctly set the penalty tax rate. For example, with heterogeneous investment opportunity sets, if the regulator sets a penalty rate structure appropriate for the average distribution of loan investment opportunities, it would penalize banks with the potential for contributing the largest social value. ${ }^{35}$

\section{Conclusions}

Given the modeling convention that equity capital can be raised at the risk-adjusted risk-free rate, if banks have access to a risk-free security investment, then collateralization of deposits with the risk-free asset costlessly resolves the moral hazard inefficiencies and insurance pricing issues addressed in the literature. When equity issuance is costly, however, the policy design issue is greatly complicated. A narrowbank deposit collateralization requirement can impose large dead-weight financing

\footnotetext{
${ }^{34}$ Their proposal is an application of previous analysis on the use of warrants to control incentive problems associated with firm debt financing (Green (1984)).

${ }^{35} \mathrm{Kim}$ and Santomero (1988a) propose an insurance premium rate that would be recalculated each period using Bayesian updating of the quality (risk) of the bank's loans based on the bank's realized asset return. In their model, there is a possible incentive-compatible adjustable rate that eliminates the bank's ex ante incentive to take high risk (socially bad) loans but it requires that the regulator know the return distributions on all of the bank's individual loan investment opportunities. John, Saunders, and Senbet (1995) modify the terms of the incentive-compatible contracts developed in John, John, and Senbet (1991) and apply them to compensation schemes of non-shareholder bank managers.
} 
costs and reduce positive NPV investments that are funded by the banking system.

Our analysis suggests that, when equity issuance is costly, moral hazard incentives can be attenuated and fair insurance pricing achieved most efficiently using bankspecific capital requirements. For most banks, the efficient moral-hazard attenuating level of required capital will be substantially less than 100 percent and will entail far smaller costs than a narrow banking requirement. If the capital requirement is defined to exclude investments in an identifiable risk-free asset, the minimum capital requirements need not reduce the insured deposit transactions balances below some efficient level.

Setting optimal capital requirements, however, imposes on bank regulators substantial information requirements. The minimum capital level required to deter moral hazard behavior and the appropriate insurance premium rate will depend on the individual bank's investment opportunity set and financing costs. Alternative approaches to eliminate moral hazard incentives, e.g. penalties or rewards based on bank performance, also can require extensive knowledge about individual bank investment opportunity sets if they are to be efficiently applied.

In our judgment, the severity of the information requirements for optimal policy design has not been sufficiently appreciated in the banking literature. Theoretical models, besides ignoring equity issuance costs, assume very simple bank investment opportunity sets. If bank investment opportunity sets were so simple, it might be plausible to assume that regulators observe individual banks' investment opportunities or can account for them with simple incentive-compatible contracting schemes. When more complex investment opportunity sets and equity issuance costs are recognized, suggested incentive approaches may not improve allocational efficiency beyond the levels attainable under more uniform capital rules. Even if more complex contracting schemes could be designed that would address real-world bank investment opportunities (an open question), the information requirements for such designs appear to be daunting. 
We are pessimistic that any single regulatory design, incentive-compatible or otherwise, can be shown to be optimal in a heterogeneous banking environment. In reality, regulatory design is likely to require choices among a set of feasible policies any one of which will be uneven in its effectiveness and less than than optimal for individual banks. The choices will continue to include minimum capital rules, variable premium rates, asset restrictions, supervision and monitoring, and possibly some formal use of incentive mechanisms. Given the bank-specific nature of socially preferred regulation, it may be appropriate that different policy alternatives be emphasized for different types of banks.

While our treatment of these policy issues has been based on a more general modeling of bank investment and financing opportunities than is typical, it is limited in a number of areas. These include avoidance of the issue of owner-manager conflicts, dynamic policy considerations, especially optimal bank closure policies, and the issue of regulatory self-interest. Further, by abstracting from bank obligations to uninsured bank creditors and counterparties, we have ignored the potentially important disciplinary role that arises from the self-interest of these parties. The implications of these additional generalizations is a task for future research. 


\section{References}

[1] Avery, Robert B. and Allen N. Berger (1991). "Risk-based capital and deposit insurance reform," The Journal of Banking and Finance, Vol 15, Nos 4/5, pp. 847-874.

[2] Buser, S. A., A.H. Chen, and E.J. Kane (1981). "Federal Deposit Insurance, Regulatory Policy, and Optimal Bank Capital," Journal of Finance, September, pp. 51-60.

[3] Campbell, Tim, Yuk-Shee Chan, and Anthony Marino, (1992). "An Incentive-Based Theory of Bank Regulation," Journal of Financial Intermediation, Vol. 2, pp. 255-276.

[4] Chan, Yuk-Shee, Stuart I Greenbaum, and Anjon Thakor, (1992). "Is Fairly-Priced Deposit Insurance Possible?" The Journal of Finance, Vol. 47, No. 1, pp. 227-245.

[5] Craine, Roger (1995). "Fairly Priced Deposit Insurance and Bank Charter Policy," The Journal of Finance, Vol. 50, No. 5, pp. 1735-1746.

[6] Diamond, Douglas W. and Philip H. Dybvig (1983). "Bank Runs, Deposit Insurance, and Liquidity," Journal of Political Economy, Vol. 91, June, pp. 401-419.

[7] Diamond, Douglas W. and Philip H. Dybvig (1986). "Banking Theory, Deposit Insurance, and Banking Regulation," Journal of Business, Vol. 59, January, pp. 55-68.

[8] Duan, Jin-Chuan and Jean-Guy Simonato, (1995). "Empirical Martingale Simulation for Asset Prices" McGill University, Montreal Canada.

[9] Fama, Eugene (1985). "What's Different About Banks?," Journal of Monetary Economics, Vol. 15, No. 1, pp. 29-39.

[10] Flannery, Mark J. (1991). "Pricing deposit insurance when the insurer measures bank risk with error," Journal of Banking and Finance, Vol. 15, Nos. 4/5, pp. 975-998.

[11] Furlong, Frederick and Michael Keeley (1989). "Capital regulation and bank risktaking: A note," Journal of Banking and Finance, Vol. 13, No. 6, pp. 883-892.

[12] Gennotte, Gerard, and David Pyle (1991). "Capital controls and bank risk," Journal of Banking and Finance, Vol. 15, No. 4/5, pp. 805-824.

[13] Giammarino, R., T. Lewis, and D. Sappington (1993). "An Incentive Approach to Banking Regulation," The Journal of Finance, Vol. 48, No. 4, pp. 1523-1542.

[14] Gjerde, Oystein and Kristian Semmen (1995). "Risk-based capital requirements and bank portfolio risk," Journal of Banking and Finance," Vol. 19, No. 7, pp. 1159-1173.

[15] Green, Richard C. (1984). "Investment Incentives, Debt, and Warrants," Journal of Financial Economics, Vol. 13, pp. 115-136, March.

[16] James, Christopher (1991). "The Losses Realized in Bank Failures," The Journal of Finance, Vol. 46, No. 4, pp. 1223-1242. 
[17] John, Kose, Teresa John, and Lemma Senbet (1991). "Risk-shifting incentives of depository institutions: A new perspective on federal deposit insurance reform," Journal of Banking and Finance, Vol. 15, Nos. 4/5 pp. 895-915, September.

[18] John, Kose, Anthony Saunders, and Lemma Senbet (1995). "A Theory of Bank Regulation, and management Compensation," New York University Salomon Center, Working Paper Series S-95-1.

[19] Kareken, John and Neil Wallace (1978). "Deposit insurance and bank regulation: A partial equilibrium exposition," Journal of Business Vol. 51, No. 3, pp. 413-438.

[20] Kim, Daesik and Anthony Santomero (1988a). "Deposit Insurance Under Asymmetric and Imperfect Information," March.

[21] Kim, Daesik and Anthony Santomero (1988b). "Risk in banking and capital Regulation," The Journal of Finance, Vol. 43, No. 5, pp. 1219-1233, December.

[22] Koehn, Michael and Anthony Santomero (1980). "Regulation of Bank Capital and Portfolio Risk," The Journal of Finance, Vol. 35, No. 5, pp. 1235-1244.

[23] Levy, Edmound, (1992). "Pricing European Average Rate Currency Options," Journal of International Money and Finance, Vol. 11, pp. 474-491.

[24] Litan, Robert (1987). What Should Banks Do?, Washington D.C.: The Brookings Institution.

[25] Marcus, Alan (1984). "Deregulation and bank financial policy," Journal of Banking and Finance, Vol. 8, No. 4, pp. 557-565.

[26] Merton, Robert (1977). "An analytical derivation of the cost of deposit insurance and loan guarantees," Journal of Banking and Finance, Vol 1, No. 1, pp. 3-11.

[27] Merton, Robert and Zvi Bodie (1993). "Deposit insurance reform: a functional approach," Journal of Monetary Economics, Vol 38, pp. 1-34.

[28] Myers, Stewart C. (1984). "Determinants of Corporate Borrowing," Journal of Financial Economics, Vol. 5, No. 4, pp. 147-175.

[29] Rochet, Jean-Charles (1992). "Capital requirements and the behavior of commercial banks," European Economic Review, Vol. 36, pp. 1137-1178.

[30] Rohn, Ehud and Avinish Verma (1986). "Pricing risk-Adjusted Deposit Insurance: An Option-based Model," The Journal of Finance, Vol. 41, No. 4, pp. 871-895. 


\section{Appendix}

\section{Derivation of Net Shareholder Value (Equation (3))}

Let $\mathrm{L}$ represent the set of loans in a bank's loan portfolio and $\mathrm{R}$ represent the set of risky markettraded securities in a bank's securities portfolio. Define $j_{1}$ to be the end-of-period cash flow generated by the bank's total risky investment portfolio,

$$
\begin{aligned}
j_{1} & =j_{L 1}+j_{M 1} \\
j_{L 1} & =\sum_{(\forall i \in L)} j_{L_{i} 1} \text { and, } j_{M 1}=\sum_{(\forall i \in R)} j_{M_{i} 1}
\end{aligned}
$$

Let $I$ represent the total initial investment in loans, and $M$ represent the total investment in market traded securities,

$$
I=\sum_{(\forall i \in L)} I_{i}, \quad \text { and } \quad M=\sum_{(\forall i \in R)} M_{i} .
$$

The total end-of-period value that accrues to the bank's shareholders including the bank's franchise value net of any distress costs is,

$$
\begin{aligned}
& j_{1}+T e^{r}+J-B \text { for } \quad j_{1}>j_{d s} \\
& j_{1}+T e^{r}+J-B-\left(\frac{d_{1}}{1-d_{1}}\right)\left(B-j_{1}-T e^{r}\right) \text { for } \quad j_{d}<j_{1}<j_{d s} \\
& \text { where, } \quad j_{d s} \equiv B-T e^{r} \text { for } \quad j_{1}<j_{d} \\
& j_{d} \equiv B-T e^{r}-\left(1-d_{1}\right) J .
\end{aligned}
$$

These conditional end-of-period values can be expressed more compactly as,

$$
y=j_{1}+T e^{r}+J-B-\frac{d_{1}}{1-d_{1}} \max \left[j_{d s}-j_{1}, 0\right]+\frac{d_{1}}{1-d_{1}} \max \left[j_{d}-j_{1}, 0\right]+\max \left[j_{d}-j_{1}, 0\right]
$$

The risk-adjusted present value of the end-of-period cash flows can be determined using equivalent martingale pricing techniques. Under the actual probability measure, the rate of return of a risky asset in equation (1) in the text is given by,

$$
\ln \left(\frac{V_{i 1}}{V_{i 0}}\right)=\mu_{i}+s_{i}^{\top} z
$$


Under an equivalent martingale measure, for asset $\mathrm{i}$, the expected rate of return $\mu_{i}$ is replaced with a risk-neutralized expected rate of return, $\mu_{i}^{w}$,

$$
\mu_{i}^{w}=\mu_{i}-\lambda^{\top} s_{i}
$$

where $\lambda$ is the vector of market prices of risk, and $z_{1}^{w}=z_{1}+\lambda$ replaces $z_{1}$ as the corresponding equivalent martingale diffusion process. Let $E^{w}($.$) denote the expectations operator under the$ martingale measure $w$. The risk-adjusted present value of the terminal value of the asset is given by its expected value under the equivalent martingale measure discounted to the present using the risk free interest rate.

For asset $i$, the risk-adjusted present value is,

$$
j_{i 0}=e^{-r} E^{w}\left(j_{i 1}\right)=e^{-r} V_{i 0} e^{\mu_{i}+\frac{1}{2} \sigma_{i}^{2}-\lambda^{\top} s_{i}}
$$

Because the expected returns of market-traded securities satisfy a no-arbitrage condition, $\mu_{M_{i}}^{w}=$ $\mu_{M_{i}}+\frac{1}{2} \sigma_{i}^{2}-\lambda^{\top} s_{M_{i}}=r \forall i$. Thus the risk-adjusted present value of the bank's market-traded securities portfolio is,

$$
e^{-r} E^{w}\left(j_{M 1}\right)=e^{-r} \sum_{(\forall i \in R)} M_{i} e^{r}=M
$$

The risk-adjusted present value of the bank's loan portfolio, $j_{L 0}$, is

$$
j_{L 0}=\sum_{(\forall i \in L)} j_{L_{i} 0}=e^{-r} \sum_{(\forall i \in L)} E^{w}\left(j_{L_{i} 1}\right)=e^{-r} \sum_{(\forall i \in L)} I_{L_{i}} e^{\mu_{L_{i}}+\frac{1}{2} \sigma_{i}^{2}-\lambda^{\top} s_{L_{i}}}
$$

$j_{L 0}+M$ is the risk-adjusted present value of the bank's total end-of-period cash flows from risky assets. In the text and numerical examples in the paper, the value of a bank's market portfolio of risky market-traded securities is treated as a single lognormal variable. This simplification is useful and inconsequential.

$J$ represents the expected value of the bank's franchise, here taken to be a fixed value that can be realized at the end of period 1 . Thus the franchise value at the start of period 1 is $e^{-r} J$. Similarly, $T e^{r}$ is a certain payment at the end of period 1 from a bank's risk-free bond investments, so its present value is $T$.

The remaining components of the the end-of-period value expression are equivalent to the cash flow payoffs that would be produced by positions in long and short European-style put options (with strikes prices of $j_{d s}$ and $j_{d}$ ) written on the underlying risky asset portfolio with payoff $j_{1}$. Their 
initial period values are

$$
\begin{aligned}
P_{D} & =e^{-r} E^{w}\left[\max \left[j_{d s}-j_{1}, 0\right]\right] \\
P_{I} & =e^{-r} E^{w}\left[\max \left[j_{d}-j_{1}, 0\right]\right] .
\end{aligned}
$$

If $j_{1}$ was lognormal, these options would have familiar Black-Scholes closed form valuations. As $j_{1}$ is distributed according to the sum of lognormal variables, Black-Scholes will not apply and numerical valuations .

The bank's equity shares have a gross value equal to: the present value of the aforementioned end-of-period returns $\left.y: j_{L 0}+M+T-B-\frac{d_{1}}{1-d_{1}}\left(P_{D}-P_{I}\right)+P_{I}\right)$, plus the up-front deposit liquidity service payments, $e^{-r} B \pi$, less the deposit insurance premium payments, $\phi B e^{-r}$, less initial outside

equity financing costs, $\frac{d_{0}}{1-d_{0}} E$ where $E$ must satisfy the financing requirement given by,

$$
E=\frac{1}{1-d_{0}} \max \left\{I+M+T+\phi(B)-(1+\pi) B e^{-r}-W, 0\right\}
$$

Initial shareholder net equity value is derived by subtracting from the gross value inside plus outside equity capital financing $(W+E)$ as well as any deposit profits net of premium payments that might have been used to finance initial investments. This yields the result in equation (3) in the text.

\section{Derivation of Bank's Economic Value-Added (Equation (5))}

Given the assumption in section 2.3 that bank shareholders capture all of the bank's economic valueadded from loans and the provision of deposit transactions or liquidity services, the bank's economic value-added is equal to the present value of the end-of-period returns realized by all bank claimants (bank shareholders, depositors, and insurer) net of initial outlays (premium payments in the case of the insurer). For depositors, the net value is zero under the assumption that the bank captures the value from deposit services. For the insurer, the end of period return is a payment equal to $\max \left\{j_{d}-j_{1}, 0\right\}$. This assumes that, in closing an insolvent bank, the insurer realizes $\left(1-d_{1}\right) J$ from the sale of the bank's franchise, i.e., the fraction realized in selling the franchise is the same as that when the bank is forced to raise equity against the franchise in a distress situation. The present value of this liability under the equivalent martingale measure is $P_{I}$ and the insurer's initial net position is $\phi B e^{-r}-P_{I}$. Adding the insurer's initial net position to shareholders net equity value gives the bank's economic value-added. This value is equal to that in equation (5). $\square$ 


\section{Proof of Propositions and Corollaries}

The end-of period values for any loan $k\left(j_{L_{k} 1}\right)$ or risky security portfolio $\left(j_{M 1}\right)$ have been assumed to be distributed lognormally. To formally prove the propositions and corollaries in the text, we further specialize the assumptions of the model so that the bank chooses among a set of loan portfolios, each of which has a lognormal distribution. With this additional assumption, the end-of-period value of the bank's risky assets $\left(j_{1}=j_{L_{k} 1}+j_{M 1}\right)$ is the sum of two lognormal variables. The additional specialization greatly simplifies the proofs by limiting the the distribution function of the sum of 2 lognormal variables.

Although $j_{L_{k} 1}$ and $j_{M 1}$ have actual lognormal distributions by assumption, the lognormal distributions of interest are the distributions implied by the equivalent martingale measure. In the lemmas that follow, we will consider end-of-period values as individual asset volatilities, $\sigma_{i}^{2}$, get infinitely large while the assets' risk-neutral drifts, $\mu_{i}^{w}$, are assumed to remain unchanged. One way for this to occur is for the increased volatility to come from increases in the size of the non-systematic components of $s_{i}$ whose market price of risk are zero.

Define $F_{n}\left(n_{1}\right)$ to be the cumulative distribution function (CDF) of the random variable $n$ evaluated at $n_{1}$, and $f_{n}\left(n_{1}\right)$ as the corresponding density function (PDF), both defined under the equivalent martingale measure. The random variables of interest are the end-of-period values under the equivalent martingale measure, $j_{L_{k} 1}, j_{M 1}$, and $j_{1}=j_{L_{k} 1}+j_{M 1}$.

It is convenient to first establish the following lemmas and conjectures.

Lemma 1 For any $j_{M 1} \ll \infty$, and any nonnegative finite investment $M$, (i) $\lim _{\sigma_{M} \rightarrow \infty}$ $F_{M}\left(j_{M 1}\right) \rightarrow 1$ uniformly; and (ii) $\lim _{\sigma_{M} \rightarrow \infty} f_{M}\left(j_{M 1}\right) j_{M 1} \rightarrow 0$ uniformly.

proof: Using a change of variables, $F_{M}\left(j_{M 1}\right)=N_{z}\left(z_{1}\right)$ where $N_{z}\left(z_{1}\right)$ is a standard normal CDF and $z_{1}=\ln \left(\frac{j_{M 1}}{M}\right) \frac{1}{\sigma_{M}}-\frac{\mu_{M}^{w}}{\sigma_{M}}+.5 \sigma_{M} \cdot \lim _{\sigma_{M} \rightarrow \infty} N_{z}\left(z_{1}\right)=N_{z}\left(\lim _{\sigma_{M} \rightarrow \infty} z_{1}\right)=N_{z}(+\infty)=1$. Further, $F_{M}\left(j_{M 1}\right)$ and $N_{z}\left(z_{1}\right)$ are continuous in $\sigma_{M}$ for all $j_{M 1} \in(0, \infty)$ so that $F_{M}\left(j_{M 1}\right)$ converges uniformly. With uniform convergence, $\lim _{\sigma_{M} \rightarrow \infty} f_{M}\left(j_{M 1}\right)=\frac{d\left(\lim _{\sigma_{M} \rightarrow \infty} F_{M}\left(j_{M 1}\right)\right)}{d j_{M 1}}=0$ from which (ii) in Lemma 1 follows immediately. ${ }^{36}$

Conjecture 1 For any $j_{M 1} \ll \infty$ and any nonnegative investment $M$, (i) $\lim _{\sigma_{M} \rightarrow \infty} F_{j}\left(j_{1}\right)$

$\rightarrow F_{L_{k}}\left(j_{L_{k} 1}\right)$ uniformly; and (ii) $\lim _{\sigma_{M} \rightarrow \infty} f_{j}\left(j_{1}\right) j_{1} \rightarrow f_{L_{k}}\left(j_{L_{k} 1}\right) j_{L_{k} 1}$ uniformly.

Because the distribution of the sum of lognormal variables does not have any simple analytic form, we are not able to prove this conjecture analytically. However, the limits in the conjecture can be

${ }^{36}$ For theorems on limit functions and uniform convergence, see Rektorys (1969), Chapter 15. 
verified numerically. Further, the intuition for the conjecture follows from Lemma 1. As the volatility of the risky market security increases without bound, its CDF uniformly approaches a distribution where virtually all the mass is concentrated at zero so that the probability that $j_{M 1} \gg 0$ approaches 0 . Therefore, the conjecture is that, for the sum of the lognormal random variables, $j_{1}=j_{L_{k} 1}+j_{M 1}$, the CDF for $j_{1}$ approaches the CDF for $j_{L_{k} 1}$ as $\sigma_{M} \rightarrow \infty$.

The following lemmas establish properties of the deposit insurance value when the bank has access to 0 NPV securities with unbounded risk.

Lemma 2 For a given loan portfolio $k$, the deposit insurance value is $P_{I}\left(L_{k}\right)=e^{-r} E^{w}\left[\max \left\{j_{d}-\right.\right.$ $\left.\left.j_{1}, 0\right\}\right]$ where $j_{d}=\bar{B}-T-J e^{-r}$ and $j_{1}=j_{L k 1}+j_{M 1}$. If this loan portfolio is combined with a risky security investment that has unbounded risk, $P_{I}\left(L_{k}\right)$ has the properties: (i) $\lim _{\sigma_{M} \rightarrow \infty} P_{I}\left(L_{k}\right)=$ $e^{-r} E^{w}\left[\max \left\{j_{d}-j_{L_{k} 1}, 0\right\}\right]$; (ii) $e^{-r} E^{w}\left[\max \left\{j_{d}-j_{L_{k} 1}, 0\right\}\right]$ is the maximum attainable value among all permitted risky securities strategies (i.e., the insurance value given loan portfolio $L_{k}$ is maximized by choosing a securities investment with unbounded risk).

proof: Part (i) is proved using Conjecture 1 (i) and (ii).

$$
\begin{aligned}
\lim _{\sigma_{M} \rightarrow \infty} P_{I}\left(L_{k}\right) & =\lim _{\sigma_{M} \rightarrow \infty} e^{-r}\left\{j_{d} F_{j}\left(j_{1}\right)-\int_{0}^{j_{d}} j_{1} f_{j}\left(j_{1}\right) d j_{1}\right\} \\
& =e^{-r}\left(j_{d} \lim _{\sigma_{M} \rightarrow \infty} F_{j}\left(j_{1}\right)-\int_{0}^{j_{d}} \lim _{\sigma_{M} \rightarrow \infty}\left\{j_{1} f_{j}\left(j_{1}\right)\right\} d j_{1}\right) \\
& \left.=e^{-r}\left(j_{d} F_{L_{k}}\left(j_{L_{k} 1}\right)-\int_{0}^{j_{d}} j_{L_{k} 1} f_{L_{k}}\left(j_{L_{k} 1}\right)\right\} d j_{L_{k} 1}\right) \quad \text { by Conjecture } 1 \\
& =e^{-r} E^{w}\left[\max \left\{j_{d}-j_{L_{k} 1}, 0\right\}\right] .
\end{aligned}
$$

To prove part (ii) note that the insurance payoff is $\max \left\{j_{d}-\left(j_{L_{k} 1}+j_{M 1}\right), 0\right\}$. Since $j_{M 1} \geq 0$, the payoff for any realization $j_{L_{k} 1}$ is a maximum if $j_{M 1}=0$. Multiplying each possible insurance payoff by its (equivalent martingale) probability given $j_{M 1}=0$ also must give the maximum probabilityweighted payoff for any $j_{L_{k}}$ realization. Therefore, given loan portfolio $k$, the discounted sum of the probability-weighted insurance payoffs is a maximized when $j_{M 1}=0$. The maximized discounted sum of the probability-weighted payoffs is $e^{-r} E^{w}\left[\max \left\{j_{d}-j_{L_{k} 1}, 0\right\}\right]$. Part (i) of this lemma established that $e^{-r} E^{w}\left[\max \left\{j_{d}-j_{L_{k} 1}, 0\right\}\right]$ is also the payoff obtained with any $j_{M^{\prime} 1}>0$ provided that $j_{M^{\prime} 1}$ has unbounded risk. This proves part (ii).

Since the insurance payoff is $\max \left\{j_{d}-j_{1}, 0\right\}$ and $j_{1} \geq 0$, the absolute maximum payoff is $\max \left\{j_{d}, 0\right\}$. Thus, $\max \left\{j_{d}, 0\right\}$ is an upper bound on the value of the insurance guarantee. The 
following two lemmas establish conditions for achieving this bound with maximum loan and security risk.

Lemma 3 A bank that invests all its funds in the risky security with unbounded risk achieves the maximum insurance value; i.e., $\lim _{\sigma_{M} \rightarrow \infty} P_{I}=e^{-r} \max \left\{j_{d}, 0\right\}$.

Lemma 4 For a bank that invests its funds in both loans and risky securities, $\lim _{\sigma_{L_{k}} \rightarrow \infty}$ $\lim _{\sigma_{M} \rightarrow \infty} P_{I}=e^{-r} \max \left\{j_{d}, 0\right\}$.

proof: For Lemma 3, the bank's asset portfolio is the risky security portfolio with end-of-period value $j_{M 1}$ and $\lim _{\sigma_{M} \rightarrow \infty} P_{I}=\lim _{\sigma_{M} \rightarrow \infty} e^{-r} E^{w}\left[\max \left\{j_{d}-j_{M 1}, 0\right\}\right]$. For $j_{d} \leq 0$, this limit is 0 .

For $j_{d} \gg 0$, the limit is $e^{-r}\left(\left\{j_{d} \lim _{\sigma_{M} \rightarrow \infty} F_{M}\left(j_{M 1}\right)-\int_{0}^{j_{d}} \lim _{\sigma_{M} \rightarrow \infty}\left\{j_{M} f_{M}\left(j_{M 1}\right)\right\} d j_{1}\right)=e^{-r} j_{d}\right.$ by Conjecture 1.

To prove Lemma 4, first apply $\lim _{\sigma_{M} \rightarrow \infty}$ to $P_{I}$ when the bank invests in both loans and risky securities. By lemma 2, this yields an insurance value written on the loan portfolio with lognormal end-of-period value $j_{L_{k} 1}$. Next apply Lemma 1 (using " $L_{k}$ " instead of " $M$ ") to get Lemma 4 . That is, $\lim _{\sigma_{L_{k}} \rightarrow \infty}\left\{\lim _{\sigma_{M} \rightarrow \infty} P_{I}\right\}=\lim _{\sigma_{L_{k}} \rightarrow \infty} P_{I}\left(L_{k}\right)=e^{-r} \max \left\{j_{d}, 0\right\}$.

Proof of Theorem 1

Proposition 1 can now be proven where the end-of-period loan portfolio $\left(j_{L_{1}}\right)$ and risky securities portfolio $\left(j_{M 1}\right)$ each take the lognormal forms defined above. When $d_{0}=d_{1}=0$, the value of the bank's K function (see equation (4) in text) given loan portfolio $L_{k}$ is

$$
\mathrm{K}\left(L_{k}\right)=P_{I}\left(L_{k}\right)+(\pi-\phi) \bar{B} e^{-r}
$$

where $P_{I}\left(L_{k}\right)=e^{-r} E^{w}\left[\max \left\{j_{d}-\left(j_{L_{k} 1}+j_{M 1}\right), 0\right\}\right]$.

First consider the case where the bank costlessly adjusts its investment in risk-free securities $T$ such that $j_{d} \equiv \bar{B}-T e^{r}-J e^{r} \leq 0$. If $\pi \geq \phi$, the bank issues maximum deposits. Since the end-of-period value on the bank's loans and securities cannot be negative, when $j_{d} \leq 0, P_{I}\left(L_{k}\right)=0$ $\forall k$ and the bank is free of default risk. In this case, the bank's net share value, $S$, is, $S=j_{L_{k} 1}-I_{k}+$ $(\pi-\phi) \bar{B} e^{-r}+J e^{-r}$. Under this default-free strategy, $S$ is maximized by maximizing loan portfolio NPV, yielding

$$
S_{F}^{*}=\max _{\forall L_{k}}\left\{j_{L_{k} 0}-I_{k}\right\}+(\pi-\phi) \bar{B} e^{-r}+J e^{-r} .
$$

Since equity issuance is costless, the bank could also select an infinite number of risky 0 NPV securities portfolios such that $j_{d}-j_{L_{k} 0}-j_{M 1}<0$ for all possible cash flow realizations. For these 
strategies, $P_{I}=0$, and maximum shareholder value is equivalent to $S_{F}^{*}$.

If the bank sets $j_{d}>0$, it faces default risk and $P_{I}>0$. When the bank faces positive default risk, there are two types of investment strategies that must be considered. One strategy limits the bank's investments to 0 NPV risky securities. From Lemma 3, the bank will maximize its deposit insurance value, and hence the value of $\mathrm{K}$, by investing in securities with unbounded risk. This yields $\mathrm{K}=\bar{B} e^{-r}(1+\pi-\phi)-T-J e^{-r}$ which is maximized by setting $T=0$. Since the bank has no loan portfolio, net shareholder value is given by,

$$
S_{R}^{*}=\bar{B} e^{-r}(1+\pi-\phi),
$$

$S_{R}^{*}$ is a "go-for-broke" strategy as the bank is taking maximum default and securities risk to maximize its deposit insurance value.

In the alternative strategy, the bank's investments include both 0 NPV risky securities and a risky loan portfolio $L_{k}$. The deposit insurance payoff is $\max \left\{j_{d}-\left(j_{L_{k} 1}+j_{M 1}\right), 0\right\}$. Lemma 2 established that the insurance value, given loan portfolio $L_{k}$, is a maximum when risky securities investments have maximum (unbounded) risk, i.e., $\lim _{\sigma_{M} \rightarrow \infty} P_{I}\left(L_{k}\right)=e^{-r} E^{w}\left[\max \left\{j_{d}-j_{L_{k} 1}, 0\right\}\right] \equiv P_{I}^{*}\left(L_{k}\right)$. Lemma 4 establishes an upper bound for $P_{I}^{*}\left(L_{k}\right) \leq \max \left\{j_{d}, 0\right\}$. Moreover it can be shown that $e^{-r} E^{w}\left[\max \left\{j_{d}-j_{L_{k} 1}, 0\right\}\right] \geq e^{-r} j_{d}-j_{L_{k} 0}$ (i.e., an option value cannot be less than its "intrinsic value"). ${ }^{37}$ Thus, the insurance value, given loan portfolio $\mathrm{k}$ and an optimal risky securities strategy, is bounded by

$$
\max \left\{j_{d}-j_{L_{k} 0}, 0\right\} \leq P_{I}^{*}\left(L_{k}\right) \leq \max \left\{j_{d}, 0\right\}
$$

Since $j_{d}=\bar{B}-T-J$, the maximization of the insurance value requires the bank to set $T=0$. These bounds on the maximum insurance value, given loan portfolio $L_{k}$, imply bounds on net shareholder value. Using $S\left(L_{k}\right)=j_{L_{k} 0}-I_{k}+\mathrm{K}\left(L_{k}\right)+J e^{-r}$, and $T=0$, the maximum net shareholder value

$$
\begin{aligned}
e^{-r} E^{w}\left[\max \left\{j_{d}-j_{L_{k} 1}, 0\right\}\right] & =e^{-r}\left(\int_{0}^{j_{d}}\left(j_{d}-j_{L_{k} 1}\right) f_{L_{k}}\left(j_{L_{k} 1}\right) d j_{L_{k} 1}\right) \\
& \geq e^{-r}\left(\int_{0}^{\infty}\left(j_{d}-j_{L_{k} 1}\right) f_{L_{k}}\left(j_{L_{k} 1}\right) d j_{L_{k} 1}\right)=e^{-r} j_{d}-j_{L_{k} 0}
\end{aligned}
$$


conditional on loan portfolio $L_{k}, S^{*}\left(L_{k}\right)$, will satisfy the bounds ${ }^{38}$

$$
(1+\pi-\phi) \bar{B} e^{-r}-I_{k} \leq S^{*}\left(L_{k}\right) \leq j_{L_{k} 0}-I_{k}+(1+\pi-\phi) \bar{B} e^{-r} .
$$

Notice that the upper bound on net shareholder value exceeds the value attainable by "going for broke" using only risky 0 NPV securities.

Under perfect access to capital markets, a bank with $\mathrm{N}$ loan portfolio alternatives will choose an investment strategy with a maximum net share value, $S^{*}$, that satisfies

$$
S^{*}=\max \left\{S_{F}^{*}, S_{R}^{*}, S^{*}\left(L_{1}\right), S^{*}\left(L_{2}\right), \ldots, S^{*}\left(L_{N}\right)\right\}
$$

Thus the bank's optimizing choice will depend on its opportunities for loan NPV and loan risk. In particular, $S_{F}^{*}$ depends on the maximum loan portfolio NPV in the bank's investment opportunity set. Further, the value of $S^{*}\left(L_{k}\right)$ depends on both NPV and risk for portfolio $L_{k}$ and the upper bound on $S^{*}\left(L_{k}\right)$ exceeds the value of a maximum risk, and Lemma 4 establishes the possibility that $S^{*}\left(L_{k}\right)$ can equal its upper bound. Whether there exists a loan portfolio $L_{k}$ such that $S^{*}\left(L_{k}\right)>S_{R}^{*}$ depends on the risk and NPV characteristics of the bank's loan investment opportunity set. Also, note that the bank's optimal loan portfolio may have a smaller NPV than the loan portfolio that includes all positive NPV loan opportunities. However, the risk obtainable from the optimal loan portfolio may be high enough such that $S^{*}\left(L_{k}\right)$ still exceed the safe-bank shareholder value, $S_{F}^{*}$.

\section{Proof of Proposition 1}

Proof follows directly from Theorem 1.

\section{Proof of Corollary 1}

If all loans in the bank's investment opportunity set have 0 or negative NPVs, i.e., $j_{L_{k} 0}-I_{k} \leq 0$, the upper bound on $S^{*}\left(L_{k}\right)$ and the value of $S_{R}^{*}$ established in the proof of Proposition 1 imply $S_{R}^{*} \geq S^{*}\left(L_{k}\right), \forall k$. That is, a bank will never choose a risky strategy with nonpositive NPV loan opportunities when 0 NPV infinite risk investments are available. Thus, the bank's optimizing choice set reduces to a securities-only "go-for-broke" strategy and a safe-bank strategy in which the bank only invests in risk-free bonds, i.e., $S^{*}=\max \left\{S_{F}^{\circ}, S_{R}^{*}\right\}$, where $S_{F}^{\circ}=(\pi-\phi) \bar{B} e^{-r}+J e^{-r}$. Since $S_{R}^{*}=\bar{B} e^{-r}(1+\pi-\phi)$, the bank chooses the safe strategy, $S_{F}^{\circ}$, if $J>\bar{B}$. Under these conditions, the bank's optimal strategy is independent of the characteristics of its loan investment opportunities.

\footnotetext{
${ }^{38}$ Note that a bank would never operate at the lower bond since it can achieve a higher net share value by making no loan investment, setting $I_{k}=0$, which is equivalent to selecting a "go-for-broke" yielding $S_{R}^{*}$.
} 
Proof of Corollary 2

The proof of Proposition 2 (below) establishes that, for a bank facing fairly-priced deposit insurance, no equity issuance costs $\left(d_{0}=0\right)$, and unrestricted access to risk-free bond investments, it is optimal to invest in all positive NPV loans. The proof of Theorem 1 establishes that an otherwise identical bank facing fixed rate deposit insurance may not find it optimal to invest in all positive NPV loans in its investment opportunity set.

Proof of Proposition 2

If $d_{0}=0$, and deposit insurance is fairly priced, the bank's optimization problem is,

$$
\max S=e^{-r} J+\max _{\forall k}\left(j_{L_{k} 0}-I_{k}\right)+\max _{0<B \leq \bar{B}} \pi B e^{-r}-\frac{d_{1}}{1-d_{1}} \min P_{D}
$$

When $\pi>0$, the optimal strategy is to set $B=\bar{B}$ and selected all positive NPV loans thereby maximizing $\left(j_{L_{k} 0}-I_{k}\right)$. If $d_{0}=0, P_{D}$ can be set to its minimum value of zero irrespective of the bank's loan portfolio and deposit level choices (see Corollary 3). This establishes Proposition 2.

\section{Proof of Corollary 3}

If there are no distress costs, $d_{1}=0$, then the value of $P_{D}$ (which depends on the probability of financial distress) is irrelevant. If $d_{1}>0, P_{D}$ can be costlessly set to 0 by purchasing a sufficient quantity of risk-free bonds or 0 NPV risky securities with appropriate end-of-period cash flow char-

acteristics. For example, if $T=\bar{B} e^{-r}$, then $P_{D}=0$ regardless of the banks loan or risky security portfolio choices. As $P_{D}=0$ is consistent with optimality, Corollary 3 is established.

Corollary 4 Provided that a bank has access to 0 NPV market-traded securities with unbounded risk, although a bank facing fixed rate deposit insurance may not invest in all the positive NPV loans in its investment opportunity set, it will never be optimal for the bank to invest in negative NPV loans in order to increase its insurance value.

\section{Proof of Corollary 4}

Conditional of the bank selecting loan portfolio $L_{k}$ and an optimal "go-for-broke" strategy that includes a market-traded securities portfolio with unbounded risk, the bank's net share value, $S^{\dagger}\left(L_{k}\right)$, is

$S^{\dagger}\left(L_{k}\right)=j_{L_{k} 0}-I_{k}+J e^{-r}+\lim _{\sigma \rightarrow \infty}\left\{\frac{1}{1-d_{1}} P_{I}\left(L_{k}\right)-\frac{d_{1}}{1-d_{1}} P_{D}\left(L_{k}\right)\right\}-\frac{d_{0}}{1-d_{0}} E\left(L_{k}\right)+(\pi-\phi) \bar{B} e^{-r}$. where $E\left(L_{k}\right)$ is the optimal amount of external equity financing required under loan portfolio $L_{k}$ and a go-for-broke capital structure strategy. An optimal go-for-broke strategy sets $T=0$. Lemma 
2 establishes that,

$$
\lim _{\sigma \rightarrow \infty} P_{I}\left(L_{k}\right)=e^{-r} E^{w} \max \left[j_{d}-j_{L_{k} 1}, 0\right]=e^{-r} E^{w} \max \left[\bar{B}-\left(1-d_{1}\right) J-j_{L_{k} 1}, 0\right] .
$$

A similar argument can be used to establish,

$$
\lim _{\sigma \rightarrow \infty} P_{D}\left(L_{k}\right)=e^{-r} E^{w} \max \left[j_{d s}-j_{L_{k} 1}, 0\right]=e^{-r} E^{w} \max \left[\bar{B}-j_{L_{k} 1}, 0\right] .
$$

Now consider loan portfolio $L_{k^{\prime}}$, a portfolio that differs from loan portfolio $L_{k}$ by an additional investment of $\$ 1$ in a negative NPV loan. Let $S^{\dagger}\left(L_{k^{\prime}}\right)$ denote the net share value generated by taking an optimal go-for-broke strategy using loan portfolio $L_{k^{\prime}}$. Log-normality implies that for all possible

realizations, $j_{L_{k^{\prime}} 1} \geq j_{L_{k} 1}$, and so $P_{I}\left(L_{k^{\prime}}\right) \leq P_{I}\left(L_{k}\right)$ and $P_{D}\left(L_{k^{\prime}}\right) \leq P_{D}\left(L_{k}\right)$. Moreover, under lognormality it is straight-forward to show that $\left[P_{I}\left(L_{k}\right)-d_{1} P_{D}\left(L_{k}\right)\right]-\left[P_{I}\left(L_{k^{\prime}}\right)-d_{1} P_{D}\left(L_{k^{\prime}}\right)\right] \geq 0$ for $d_{1} \geq 0$. Thus $S^{\dagger}\left(L_{k}\right)-S^{\dagger}\left(L_{k^{\prime}}\right)>0$ even if $d_{0}=0$.

Proof of Proposition 3

When $\pi>0$, deposit insurance is fairly-priced, and the bank has costless access to equity capital $\left(d_{0}=0\right)$ and unlimited access to risk-free bond investments, Proposition 2 and Corollary 3 established that the bank's maximum net shareholder value, $S^{\diamond}$, is

$$
S^{\diamond}=e^{-r} J+\max _{\forall k}\left(j_{L_{k} 0}-I_{k}\right)+\pi \bar{B} e^{-r} .
$$

If the bank is required to collateralize all deposits, $P_{I}=P_{D}=0$, and the bank's optimization problem becomes,

$$
S^{\diamond \diamond}=e^{-r} J+\max _{\forall k}\left(j_{L_{k} 0}-I_{k}\right)+(\pi-\phi) \bar{B} e^{-r} .
$$

$S^{\diamond \diamond}$ is equivalent to $S^{\diamond}$ if $\phi=0$.

Proposition 4 Assuming that the bank faces potential equity issuance costs or does not have unlimited access to $0 N P V$ securities with unbounded risk, as long as any capital requirement is initially set below a 100 percent risk-asset capital level, an increase in the bank's capital requirement may induce the bank to increase, decrease, or leave unchanged the risk in its asset portfolio. Such changes will result in an indeterminate change in the value of the bank's insurance guarantee; the direction and the magnitude of the change in the value of the insurance guarantee will depend on the characteristics of the bank's loan investment opportunity set. 


\section{Share Value Optimization Under Alternative Minimum Capital Requirements}

\begin{tabular}{|c|c|c|c|c|c|c|}
\hline $\begin{array}{c}\text { loan } \\
\text { number }\end{array}$ & $\begin{array}{c}\text { loan } \\
\text { amount }\end{array}$ & $\begin{array}{l}\text { expected } \\
\text { return }\end{array}$ & $\begin{array}{l}\text { systematic } \\
\text { (priced) risk }\end{array}$ & $\begin{array}{c}\text { non-systematic } \\
\text { risk }\end{array}$ & $\begin{array}{c}\text { total } \\
\text { risk }\end{array}$ & NPV \\
\hline \multicolumn{7}{|c|}{ Loan Opportunity Set } \\
\hline 1 & 88 & .19 & .08 & .25 & .26 & 5.44 \\
\hline 2 & 10 & .15 & .10 & 1.50 & 1.50 & 0 \\
\hline 3 & 100 & .25 & .10 & .30 & .32 & 10.52 \\
\hline \multicolumn{7}{|c|}{$\underline{\text { Risky Market-Traded Security }}$} \\
\hline & & .35 & .30 & .20 & .36 & 0 \\
\hline
\end{tabular}

${ }^{a}$ For definitions of items in the table, see footnotes in Table 1 in the text.

Share Value Optimization ${ }^{a}$

\begin{tabular}{|c|c|c|c|c|c|c|c|}
\hline Minimum & & & & Net & Net & Net & \\
\hline Capital & & Risky & Riskless & Share & Firm & Insurance & Capital \\
\hline Required $^{b}$ & Loans & Security & Security & Value & Value & Liability $^{c}$ & Ratio \\
\hline$\geq 0$ & 1,3 & 2.24 & 0.00 & 56.08 & 54.25 & 1.84 & .00 \\
\hline$\geq .04$ & $1,2,3$ & 0.00 & 0.20 & 54.54 & 53.25 & 2.20 & .04 \\
\hline
\end{tabular}

${ }^{a}$ Model parameters: $d_{0}=.3, d_{1}=.4, W=0, J=40, \bar{B}=200, \pi=.025, \phi=.01, r=.05$.

${ }^{b}$ Book capital to risk assets defined as loans plus risky securities.

${ }^{c}$ Includes value of insurer-borne distress costs and is net of insurance premium paid.

\section{Proof of Proposition 4}

If equity issuance costs are zero and there is access to 0 NPV securities with unbounded risk, the bank can satisfy any required capital ratio without altering its optimized net shareholder value by raising the required equity and investing the proceeds in the unbounded risk 0 NPV security. 0 NPV security investments do not affect the net value of the bank's investments and, by Lemma 2 above, the investment of capital into an unbounded risk security does do not affect the bank's deposit insurance value (or the value of distress costs). When subject to equity issuance costs and restricted access to a 0 NPV security with unbounded risk, there is a threshold capital requirement that will eliminate any moral hazard incentives. However, the relation between the capital requirement and bank risk incentives is not monotonic.

Here, we illustrate a bank's adjustment to an increase in the required minimum capital ratio 
that results in an increase in the insurer's liability. ${ }^{39}$ The example assumes bank share value maximization, a fixed insurance premium rate, positive equity issuance costs, and potential distress costs. A bank loan and market security investment opportunity set is presented in the top panel of the accompanying table. Net share-value maximizing results under alternative minimum risk-asset capital requirements are reported in the bottom panel of the table. ${ }^{40}$ The first row in the bottom panel reports the bank's optimizing results assuming only that the required minimum risk-asset capital ratio is non-negative. The second row reports results when the required minimum risk-asset capital ratio is 4 percent. Under the higher required capital ratio, the bank adds a high-risk, low NPV loan which increases the insurer's liability (column 7). In contrast to Gennotte and Pyle (1991) and despite the incurrence of equity issuance costs, the higher capital requirement induces the bank to increase its asset size as it increases the insurer's liability. ${ }^{41}$

\footnotetext{
${ }^{39}$ Avery and Berger (1991, pp. 850-1), with a different model, give another example where an increase in the capital requirement causes the bank to increase its insolvency probability and the insurer's expected payout.

${ }^{40}$ Optimizing values are derived numerically. See footnote no. 23 in text for details.

${ }^{41}$ Except for the upfront net payment on deposit issuance, $(\pi-\phi) \bar{B}$, all equity capital is raised externally. For definitions and explanation of terms in the tables, see Table 1 in text and discussion.
} 